\title{
Engaging Stakeholders to Define Feasible and Desirable Agricultural Conservation in Western Lake Erie Watersheds
}

Margaret McCahon Kalcic, Christine Kirchhoff, Nathan Bosch, Rebecca Logsdon Muenich, Michael Murray, Jacob Griffith Gardner, Donald Scavia

\section{SUPPORTING INFORMATION}

\section{Contents}

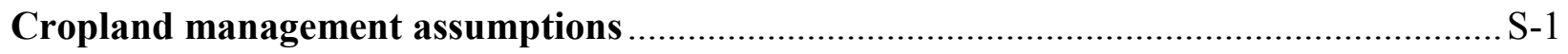

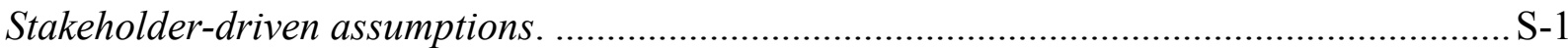

Table S1: Additional data sources to improve farm management assumptions in the SWAT model based on stakeholder feedback. ..........................................................................

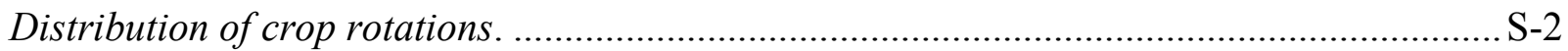

Figure S1: Annual crop percentages in the Maumee watershed from 2007-2012 from the NASS Cropland Data Layer........................................................................................... S-2

Table S2: Simplified crop rotations and percentages across the watershed............................ S-2

Figure S2: The relationship between rotations containing wheat and very poorly drained soils, and how this was reproduced in the SWAT model ...............................................................

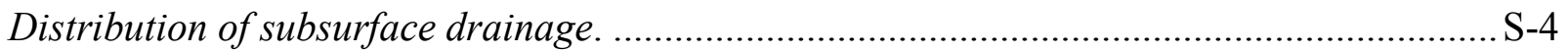

Figure S3: Result of the estimate of tile drained land ..................................................... S-4

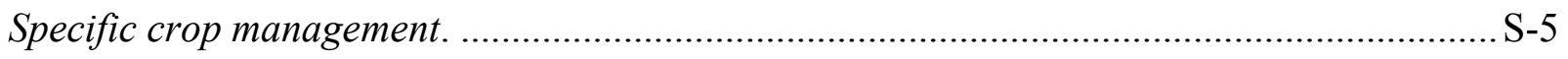

Table S3: Management (.mgt) for CS rotation ..................................................................... S-5

Table S4: Management (.mgt) for CSS rotation …………................................................ S-6

Table S5: Management (.mgt) for CSWCSSW rotation ……………………………........ S-6

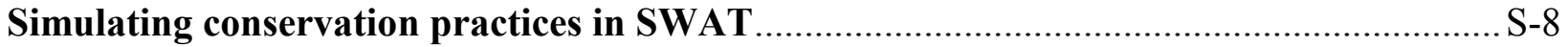

Table S6: Details on simulation of conservation practices in SWAT scenarios ...................... S-8

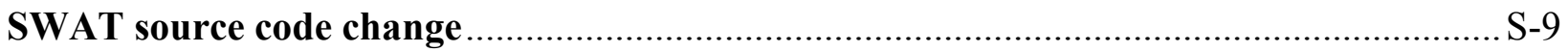




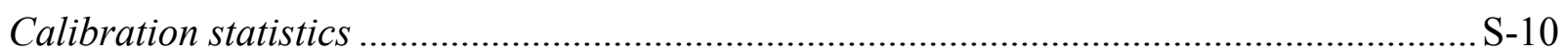

Graphical measures for the calibration period (2001-2006).............................................. S-11

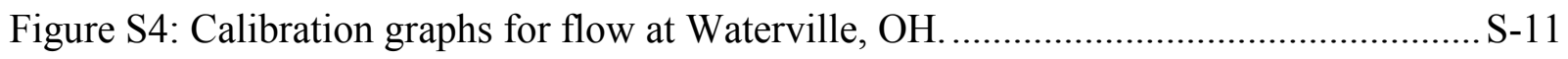

Figure S5: Calibration graphs for sediment loading at Waterville, $\mathrm{OH}$................................ S-12

Figure S6: Calibration graphs for TP loading at Waterville, $\mathrm{OH}$........................................ S-13

Figure S7: Calibration graphs for DRP loading at Waterville, OH. ...................................... S-14

Figure S8: Calibration graphs for TN loading at Waterville, OH....................................... S-15

Figure S9: Calibration graphs for nitrate loading at Waterville, OH. .................................. S-16

Graphics measures for the validation period (2001-2006)................................................. S-17

Figure S10: Validation graphs for flow at Waterville, OH.............................................. S-17

Figure S11: Validation graphs for sediment at Waterville, $\mathrm{OH}$......................................... S-18

Figure S12: Validation graphs for TP at Waterville, $\mathrm{OH}$.................................................. S-19

Figure S13: Validation graphs for DRP at Waterville, OH............................................... S-20

Figure S14: Validation graphs for TN at Waterville, $\mathrm{OH}$.................................................. S-21

Figure S15: Validation graphs for nitrate at Waterville, $\mathrm{OH}$............................................ S-22

30-year annual, monthly, and daily time series plots ....................................................... S-23

Figure S16: 30-year time series plots of flow at Waterville, $\mathrm{OH}$.......................................... S-23

Figure S17: 30-year time series plots of sediment loading at Waterville, $\mathrm{OH}$........................ S-24

Figure S18: 30-year time series plots of TP loading at Waterville, OH............................. S-25

Figure S19: 30-year time series plots of DRP loading at Waterville, OH. ........................... S-26

Figure S20: 30-year time series plots of TN loading at Waterville, OH............................... S-27

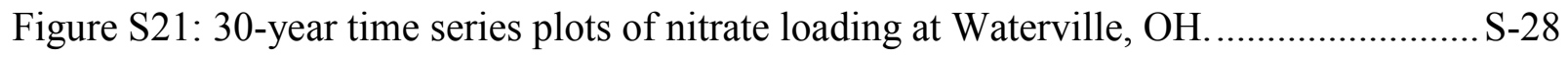

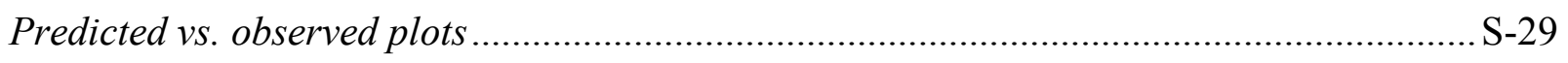

Figure S22: Predicted vs. observed plots for flow, sediment, and TP loading ...................... S-29

Figure S23: Predicted vs. observed plots for DRP, TN, and nitrate loading ........................ S-30 


\section{Cropland management assumptions}

\section{Stakeholder-driven assumptions}

Cropland management assumptions for the model were based in many ways on stakeholder involvement, as shown in Table S1.

Table S1: Additional data sources to improve farm management assumptions in the SWAT model based on stakeholder feedback.

\begin{tabular}{|c|c|c|}
\hline $\begin{array}{l}\text { Management } \\
\text { assumptions }\end{array}$ & Data source & Details \\
\hline Crop rotations & $\begin{array}{l}\text { NASS Cropland Data Layer } \\
\text { (CDL) } \\
\text { (http://www.nass.usda.gov/re } \\
\underline{\text { search/Cropland/SARS1a.ht }} \\
\underline{\text { m) }}\end{array}$ & $\begin{array}{l}\text { We studied } 6 \text { years of pixel-level rotations developed in } \\
\text { ArcGIS as a combination of } 6 \text { CDL layers. We used the } \\
\text { frequency of corn (C), soybean (S), and wheat (W), along with } \\
\text { the most common order they appear in rotation, to design } 3 \\
\text { realistic rotations for row crops in the watershed: CS, CSS, and } \\
\text { CSWCSSW. More information is provided in the next section. }\end{array}$ \\
\hline $\begin{array}{l}\text { Spatial location } \\
\text { of winter wheat } \\
\text { in rotations }\end{array}$ & $\begin{array}{l}\text { SSURGO soils drainage class } \\
\text { (http://www.nrcs.usda.gov/w } \\
\text { ps/portal/nrcs/detail/soils/sur } \\
\text { vey/geo/?cid=nrcs142p2_053 } \\
\underline{627)}\end{array}$ & $\begin{array}{l}\text { We identified a spatial relationship between rotations } \\
\text { containing wheat and soil characterization of 'very poorly } \\
\text { drained' and decided to preferentially apply wheat rotations on } \\
\text { 'very poorly drained' soils in the SWAT model. More } \\
\text { information is provided in the next section. }\end{array}$ \\
\hline $\begin{array}{l}\text { Fertilization rates } \\
\text { - state-level } \\
\text { trends }\end{array}$ & $\begin{array}{l}\text { Fertilizer use dataset } \\
\text { (http://www.ers.usda.gov/dat } \\
\text { a-products/fertilizer-use-and- } \\
\text { price.aspx) }\end{array}$ & $\begin{array}{l}\text { We looked at the State of Ohio trends in fertilization of corn, } \\
\text { soybeans, and wheat to determine if there were any trends to } \\
\text { apply in the study period (1981-2010). }\end{array}$ \\
\hline $\begin{array}{l}\text { Fertilization rates } \\
\text { - county-level } \\
\text { nutrient balance }\end{array}$ & $\begin{array}{l}\text { County-Level Estimates of } \\
\text { Nutrient Inputs to the Land } \\
\text { Surface of the Conterminous } \\
\text { United States, 1982-2001 } \\
\text { (http://pubs.usgs.gov/sir/2006 } \\
\underline{\text { 5012/) }}\end{array}$ & $\begin{array}{l}\text { We analyzed estimates of on-farm phosphorus and nitrogen } \\
\text { applications from inorganic fertilizers as well as confined and } \\
\text { unconfined manure for each county in the Maumee. We then } \\
\text { applied this total amount of nutrients over the entire watershed } \\
\text { based on crop needs, to ensure the mass balance for the } \\
\text { watershed was accurate for the 1982-2001 time period, for } \\
\text { which we had estimates. }\end{array}$ \\
\hline $\begin{array}{l}\text { Manure } \\
\text { application rates } \\
\text { and types }\end{array}$ & $\begin{array}{l}\text { NASS Ag. Census data } \\
\text { (http://www.nass.usda.gov/Q } \\
\text { uick_Stats/) and manure } \\
\text { nutrient content calculations } \\
\text { (http://pubs.usgs.gov/sir/2006 } \\
\text { 15012/pdf/sir2006 5012.pdf) }\end{array}$ & $\begin{array}{l}\text { We calculated the total number of livestock (cattle, poultry, and } \\
\text { swine) for each county in the Maumee to determine the relative } \\
\text { contribution of each type of livestock to nitrogen and } \\
\text { phosphorus applications from manure across the watershed. } \\
\text { Then we apportioned the manure applications in SWAT to each } \\
\text { of these types. }\end{array}$ \\
\hline $\begin{array}{l}\text { Tillage by crop } \\
\text { type }\end{array}$ & $\begin{array}{l}\text { Conservation Technology } \\
\text { Innovation Center (CTIC) } \\
\text { database } \\
\text { (http://www.ctic.purdue.edu/) }\end{array}$ & $\begin{array}{l}\text { We used the previously-purchased CTIC data for most } \\
\text { Maumee counties for the period around } 2005 \text { to estimate the } \\
\text { percent of corn, soybeans, and wheat managed with } \\
\text { conventional tillage and no-tillage. Then we applied these } \\
\text { portions of crop tillage to the management files for each crop } \\
\text { rotation so that, across the watershed and across rotations, } \\
\text { tillage would be similar to what farmers are really doing in } \\
\text { their fields. We also chose to incorporate phosphorus } \\
\text { applications soon after tillage in each rotation to assume } \\
\text { farmers are doing fairly 'good' practices whenever possible. }\end{array}$ \\
\hline
\end{tabular}




\section{Distribution of crop rotations}

Recent estimates of crop rotations were derived from overlaying datasets for the available years (2007-2012) of the National Agricultural Statistics Service Cropland Data Layer (CDL). From the CDL we calculated the average percentage of the watershed each year in row crops was $23 \%$ for corn, $33 \%$ for soybeans, and $7 \%$ for winter wheat, adding up to $63 \%$ of the watershed. All cropland was considered to be in one or more of these three crops, as the next-most-dominant crop was alfalfa at $1 \%$ of the watershed area, as shown in Figure S1:

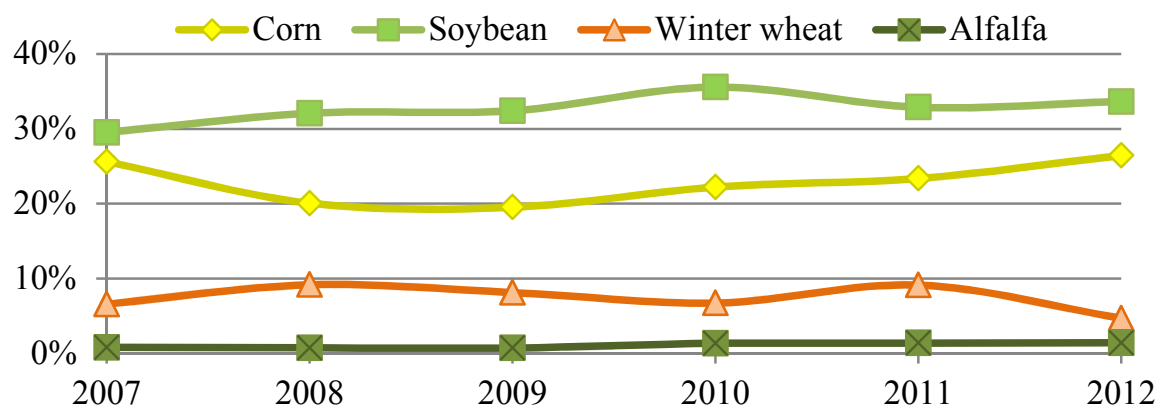

Figure S1: Annual crop percentages in the Maumee watershed from 2007-2012 from the NASS Cropland Data Layer.

To overlay the CDL layers, each raster was reclassified so that pixels had a value of 1 for corn, 2 for soybean, 3 for wheat, and 0 for other land uses. The values were added to a separate column for all six years so that a corn-soybean rotation would look like '121212' or '212121'. The result was over 5,700 separate 'rotations', many of which were extremely small fractions of the watershed. To summarize and determine the most representative set of rotations from this set we considered the 111 rotations covering at least $0.1 \%$ of the watershed, which summed up to $44 \%$ of the watershed area. We analyzed the percentage of these rotations that contained each crop (corn, soybean, and wheat), and found that $92 \%$ of these 6 -year rotations had corn, $97 \%$ had soybean, and $43 \%$ had wheat. The most common rotations were corn-soybean ('CS)', cornsoybean-soybean ('CSS'), and a rotation containing all three crops. Wheat was most often grown after soybeans and before corn. With all of this information, we settled upon three rotations for the watershed (Table S2).

Table S2: Simplified crop rotations and percentages across the watershed.

\begin{tabular}{|l|l|l|l|l|}
\hline \multirow{2}{*}{$\begin{array}{l}\text { Most common } \\
\text { rotations: }\end{array}$} & $\begin{array}{l}\text { Annual coverage of each } \\
\text { rotation in row cropland: }\end{array}$ & \multicolumn{3}{|l|}{$\begin{array}{l}\text { Annual coverage of each } \\
\text { crop in row cropland: }\end{array}$} \\
\hline & & Corn & Soybean & Wheat \\
\hline CS & $28 \%^{1}$ & $14 \%$ & $14 \%$ & $0 \%$ \\
\hline CSS & $29 \%^{1}$ & $10 \%$ & $19 \%$ & $0 \%$ \\
\hline CSWCSSW & $43 \%^{2}$ & $12 \%$ & $18 \%$ & $12 \%$ \\
\hline Total coverage: & $\mathbf{1 0 0 \%}$ & $\mathbf{3 6 \%}{ }^{1}$ & $\mathbf{5 2 \%}{ }^{1}$ & $\mathbf{1 2 \%}{ }^{1}$ \\
\hline
\end{tabular}

${ }^{1}$ We varied the abundance of CS and CSS to ensure coverage of each crop seen in the CDL.

${ }^{2}$ We ensured $43 \%$ of cropland had wheat in its rotation. 
Once we had determined the abundance of each rotation, we developed management files for these rotations and applied them to the model so that the start-year varied randomly across the watershed. We identified a visual pattern between rotations containing wheat and location on very poorly drained soils. We decided to apply $80 \%$ of rotations containing winter wheat in locations with very poorly drained soils to approximate this visual pattern. Figure S2 shows how the approach might look at the watershed-level:

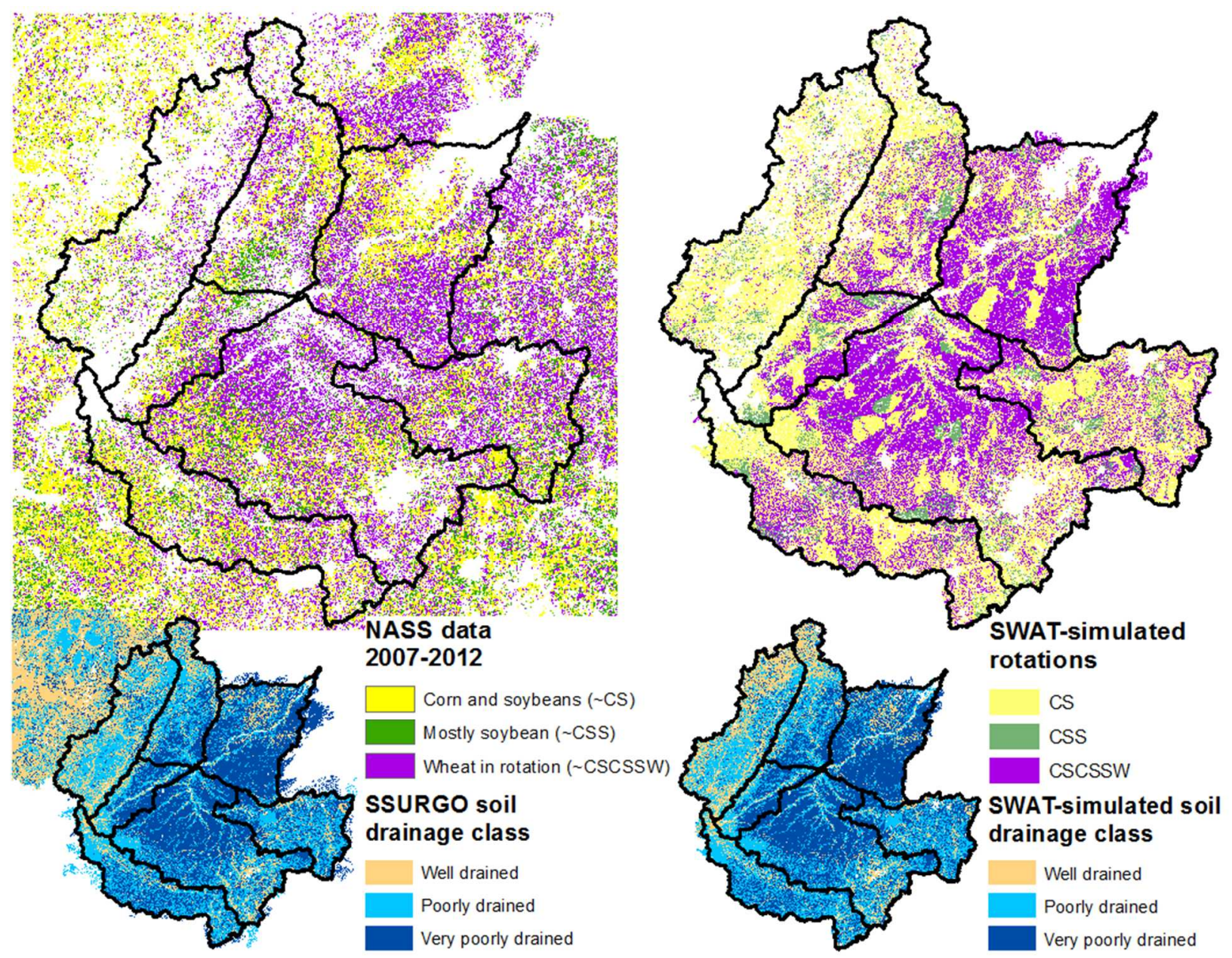

Figure S2: The relationship between rotations containing wheat (purple) and very poorly drained soils (dark blue) on the left, and how this was reproduced in the SWAT model on the right. 


\section{Distribution of subsurface drainage}

All cropland that was characterized by poor soil drainage by the U.S. SSURGO soils data was assumed to have subsurface drainage. Figure $\mathrm{S} 3$ shows the distribution of this estimate across the Maumee watershed and several nearby tributaries to Lake Erie.

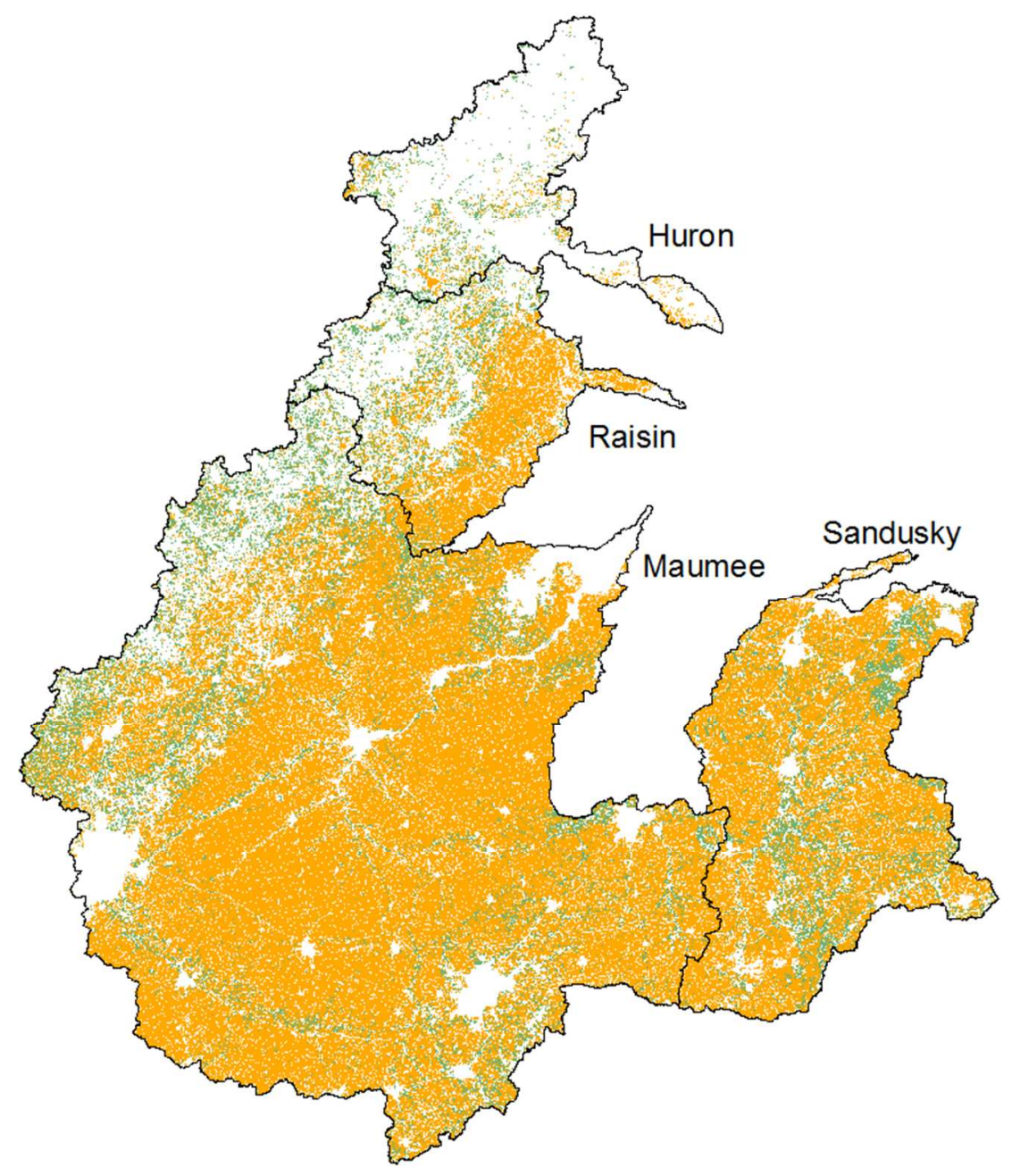

Tile drained estimate (by soil drainage class)

Cropland not estimated to be tile-drained

Figure S3: Result of the estimate of tile drained land for several watersheds draining to Lake Erie. Cropland with predominantly poorly, very poorly, or somewhat poorly drained soils was estimated to be drained with subsurface drains. 


\section{Specific crop management}

Specific crop management operations for each rotation are detailed in the tables below. For information on specific fertilizer or tillage codes, see appendices of Arnold et al. (2012).

Table S3: Management (.mgt) for corn-soybean (CS) rotation

Year 1 Operations

Adding $143 \mathrm{~kg} /$ ha of DAIRY-FR fertilizer with 100\% on surface on April 15

Adding $74 \mathrm{~kg} /$ ha of BEEF-FR fertilizer with $100 \%$ on surface on April 15

Adding $157 \mathrm{~kg} /$ ha of SWINE-FR fertilizer with 100\% on surface on April 15

Adding $74 \mathrm{~kg} /$ ha of LAYER-FR fertilizer with 100\% on surface on April 15

Adding $14 \mathrm{~kg} /$ ha of BROIL-FR fertilizer with 100\% on surface on April 15

Adding $27 \mathrm{~kg} /$ ha of Elem-P fertilizer with $100 \%$ on surface on April 15

Adding $8 \mathrm{~kg} / \mathrm{ha}$ of Elem-N fertilizer with $100 \%$ on surface on April 15

Tillage operation (Fldcge15) occurring on April 18

Adding $150 \mathrm{~kg} / \mathrm{ha}$ of Elem-N fertilizer with $0 \%$ on surface on April 21

Adding pesticide on April 21

Planting CORN on May 6

Harvesting and killing CORN on October 14

Year 2 Operations

Tillage operation (Zerotill) occurring on May 24

Planting SOYB on May 24

Harvesting and killing SOYB on October 7

Adding $143 \mathrm{~kg} /$ ha of DAIRY-FR fertilizer with $100 \%$ on surface on October 10

Adding $74 \mathrm{~kg} /$ ha of BEEF-FR fertilizer with $100 \%$ on surface on October 10

Adding $157 \mathrm{~kg} /$ ha of SWINE-FR fertilizer with $100 \%$ on surface on October 10

Adding $74 \mathrm{~kg} /$ ha of LAYER-FR fertilizer with $100 \%$ on surface on October 10

Adding $14 \mathrm{~kg} /$ ha of BROIL-FR fertilizer with $100 \%$ on surface on October 10

Adding $27 \mathrm{~kg} /$ ha of Elem-P fertilizer with $100 \%$ on surface on October 10

Adding $8 \mathrm{~kg} /$ ha of Elem-N fertilizer with $100 \%$ on surface on October 10

Tillage operation (Chplle15) occurring on October 14

Year 3 Operations

Adding $143 \mathrm{~kg} /$ ha of DAIRY-FR fertilizer with 100\% on surface on April 15

Adding $74 \mathrm{~kg} /$ ha of BEEF-FR fertilizer with $100 \%$ on surface on April 15

Adding $157 \mathrm{~kg} / \mathrm{ha}$ of SWINE-FR fertilizer with $100 \%$ on surface on April 15

Adding $74 \mathrm{~kg} /$ ha of LAYER-FR fertilizer with 100\% on surface on April 15

Adding $14 \mathrm{~kg} / \mathrm{ha}$ of BROIL-FR fertilizer with $100 \%$ on surface on April 15

Tillage operation (Fldcge15) occurring on April 18

Adding $150 \mathrm{~kg} /$ ha of Elem-N fertilizer with $0 \%$ on surface on April 21

Adding pesticide on April 21

Planting CORN on May 6

Harvesting and killing CORN on October 14

Year 4 Operations

Tillage operation (Fldcge15) occurring on May 11

Planting SOYB on May 24

Harvesting and killing SOYB on October 7

Adding $143 \mathrm{~kg} /$ ha of DAIRY-FR fertilizer with $100 \%$ on surface on October 10 Adding $74 \mathrm{~kg} /$ ha of BEEF-FR fertilizer with $100 \%$ on surface on October 10

Adding $157 \mathrm{~kg} /$ ha of SWINE-FR fertilizer with $100 \%$ on surface on October 10

Adding $74 \mathrm{~kg} / \mathrm{ha}$ of LAYER-FR fertilizer with $100 \%$ on surface on October 10

Adding $14 \mathrm{~kg} /$ ha of BROIL-FR fertilizer with $100 \%$ on surface on October 10

Tillage operation (Chplle15) occurring on October 14 
Table S4: Management (.mgt) for corn-soybean-soybean (CSS) rotation

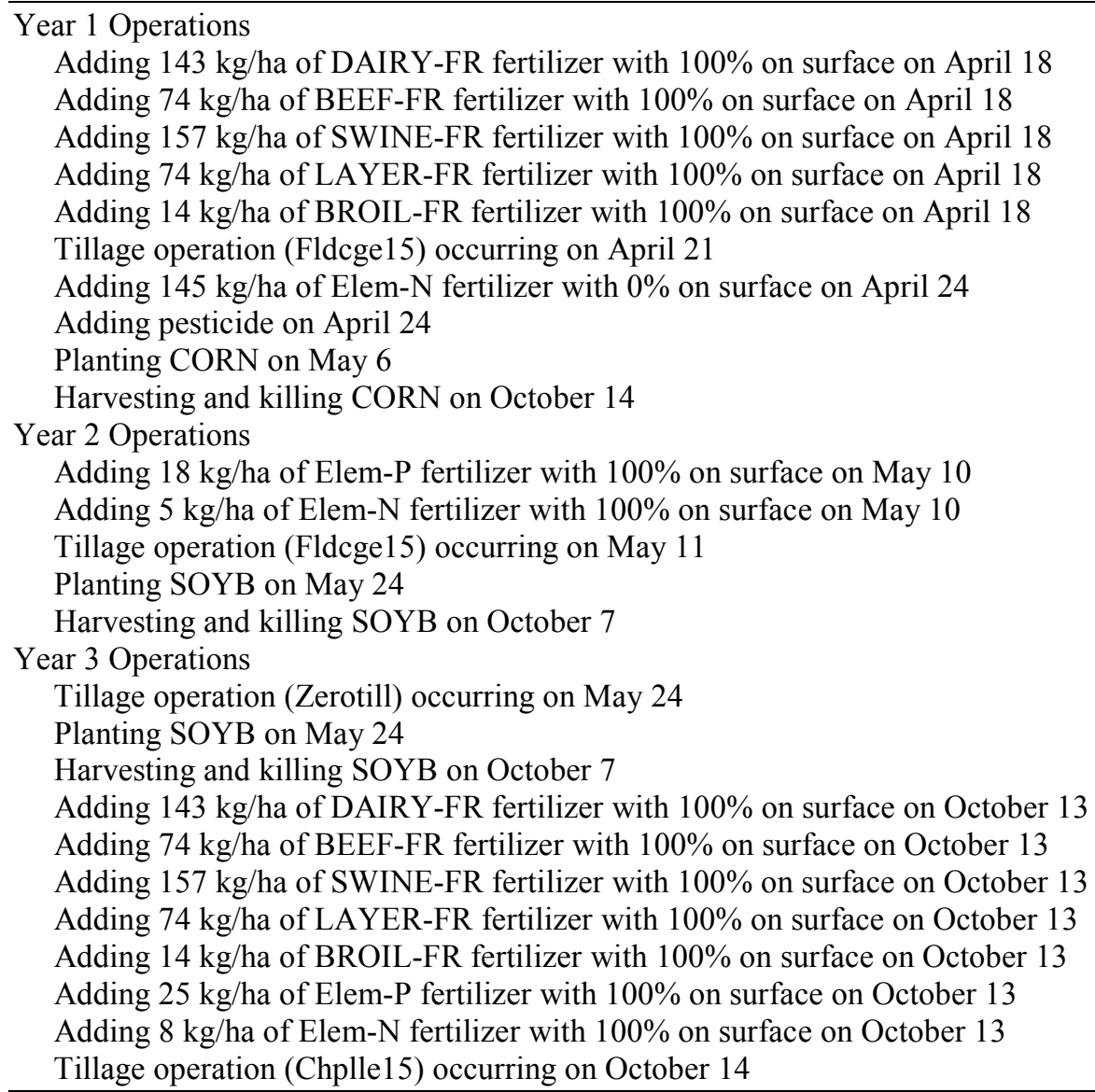

Table S5: Management (.mgt) for corn-soybean-wheat-corn-soybean-soybean-wheat (CSWCSSW) rotation

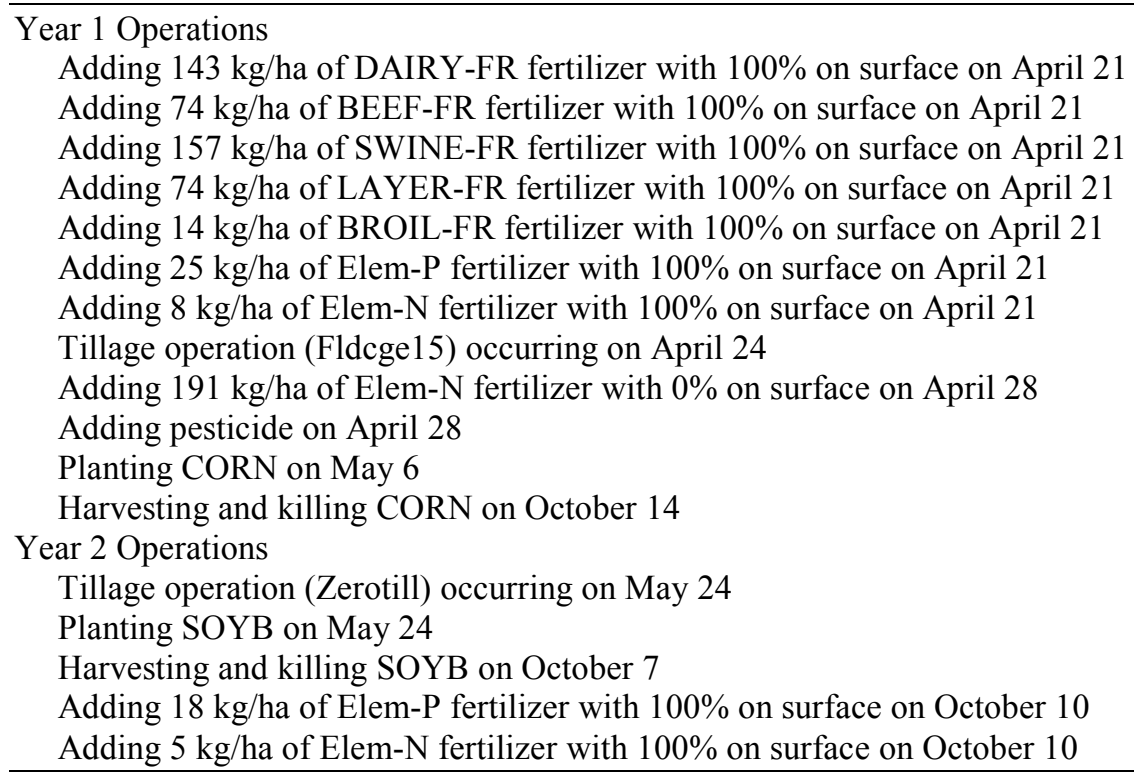


Planting WWHT on October 11

Year 3 Operations

Adding $96 \mathrm{~kg} /$ ha of Elem-N fertilizer with $0 \%$ on surface on April 15

Harvesting and killing WWHT on July 15

Adding $143 \mathrm{~kg} /$ ha of DAIRY-FR fertilizer with $100 \%$ on surface on September 15

Adding $74 \mathrm{~kg} /$ ha of BEEF-FR fertilizer with $100 \%$ on surface on September 15

Adding $157 \mathrm{~kg} /$ ha of SWINE-FR fertilizer with $100 \%$ on surface on September 15

Adding $74 \mathrm{~kg} /$ ha of LAYER-FR fertilizer with $100 \%$ on surface on September 15

Adding $14 \mathrm{~kg} /$ ha of BROIL-FR fertilizer with $100 \%$ on surface on September 15

Adding $25 \mathrm{~kg} /$ ha of Elem-P fertilizer with $100 \%$ on surface on September 15

Adding $8 \mathrm{~kg} /$ ha of Elem-N fertilizer with $100 \%$ on surface on September 15

Tillage operation (Chplle15) occurring on September 18

Year 4 Operations

Adding $143 \mathrm{~kg} /$ ha of DAIRY-FR fertilizer with 100\% on surface on April 21

Adding $74 \mathrm{~kg} /$ ha of BEEF-FR fertilizer with $100 \%$ on surface on April 21

Adding $157 \mathrm{~kg} /$ ha of SWINE-FR fertilizer with 100\% on surface on April 21

Adding $74 \mathrm{~kg} /$ ha of LAYER-FR fertilizer with 100\% on surface on April 21

Adding $14 \mathrm{~kg} /$ ha of BROIL-FR fertilizer with 100\% on surface on April 21

Tillage operation (Fldcge15) occurring on April 24

Adding $191 \mathrm{~kg} / \mathrm{ha}$ of Elem-N fertilizer with $0 \%$ on surface on April 28

Adding pesticide on April 28

Planting CORN on May 6

Harvesting and killing CORN on October 14

Year 5 Operations

Adding $18 \mathrm{~kg} /$ ha of Elem-P fertilizer with $100 \%$ on surface on May 10

Adding $5 \mathrm{~kg} / \mathrm{ha}$ of Elem-N fertilizer with $100 \%$ on surface on May 10

Tillage operation (Fldcge15) occurring on May 11

Planting SOYB on May 24

Harvesting and killing SOYB on October 7

Year 6 Operations

Tillage operation (Zerotill) occurring on May 24

Planting SOYB on May 24

Harvesting and killing SOYB on October 7

Adding $18 \mathrm{~kg} /$ ha of Elem-P fertilizer with $100 \%$ on surface on October 10

Adding $5 \mathrm{~kg} /$ ha of Elem-N fertilizer with $100 \%$ on surface on October 10

Tillage operation (Chplle15) occurring on October 11

Planting WWHT on October 12

Year 7 Operations

Adding $96 \mathrm{~kg} / \mathrm{ha}$ of Elem-N fertilizer with $0 \%$ on surface on April 15

Harvesting and killing WWHT on July 15

Adding $143 \mathrm{~kg} /$ ha of DAIRY-FR fertilizer with $100 \%$ on surface on September 15 Adding $74 \mathrm{~kg} /$ ha of BEEF-FR fertilizer with $100 \%$ on surface on September 15

Adding $157 \mathrm{~kg} /$ ha of SWINE-FR fertilizer with $100 \%$ on surface on September 15

Adding $74 \mathrm{~kg} / \mathrm{ha}$ of LAYER-FR fertilizer with $100 \%$ on surface on September 15

Adding $14 \mathrm{~kg} /$ ha of BROIL-FR fertilizer with 100\% on surface on September 15

Tillage operation (Chplle15) occurring on September 18

\section{Reference}

Arnold JG, Kiniry JR, Srinivasan R, Williams JR, Haney EB, Neitsch SL. 2012. Soil \& Water Assessment Tool Input/Output Documentation, Version 2012. Texas Water Resources Institute report TR-439. Available at: http://swat.tamu.edu/media/69296/SWAT-IO-Documentation2012.pdf 


\section{Simulating conservation practices in SWAT}

Table S6: Details on simulation of conservation practices in SWAT scenarios

\begin{tabular}{|c|c|c|}
\hline Type of practice & $\begin{array}{l}\text { Conservation } \\
\text { practice }\end{array}$ & Simulation in SWAT \\
\hline \multirow[t]{3}{*}{$\begin{array}{l}\text { Nutrient } \\
\text { placement }\end{array}$} & $\begin{array}{l}\text { Continuous no- } \\
\text { tillage }\end{array}$ & $\begin{array}{l}\text { Removed all tillage operations in .mgt files for row croplands (corn, } \\
\text { soybean, and wheat). }\end{array}$ \\
\hline & $\begin{array}{l}\text { Broadcast } \\
\text { fertilizer and/or } \\
\text { manure }\end{array}$ & $\begin{array}{l}\text { Applied all P-containing fertilizers and manures to the top of the soil } \\
\text { surface (FRT_SURFACE = 1) in .mgt files, and moved any subsequent } \\
\text { tillage operations to before the application so that fertilizers and } \\
\text { manures were not incorporated into the soil in the season they were } \\
\text { applied. }\end{array}$ \\
\hline & $\begin{array}{l}\text { Subsurface- } \\
\text { applied fertilizer } \\
\text { and/or manure }\end{array}$ & $\begin{array}{l}\text { Applied P-containing fertilizers and/or manures to the subsurface of the } \\
\text { soil (FRT_SURFACE }=0 \text {, which defaults to FRT_SURFACE }=0.2 \text { ) in } \\
\text {.mgt files. }\end{array}$ \\
\hline \multirow[t]{3}{*}{ Nutrient timing } & $\begin{array}{l}\text { Spring P } \\
\text { applications }\end{array}$ & $\begin{array}{l}\text { Applied all P-containing fertilizers and manures in the spring season } \\
\text { (pre-plant) for corn and soybeans. }\end{array}$ \\
\hline & $\begin{array}{l}\text { Winter } \\
\text { application of } \\
\text { manure }\end{array}$ & $\begin{array}{l}\text { Applied all manure that would have been applied in a given year on } \\
\text { January } 20 .\end{array}$ \\
\hline & $\begin{array}{l}\text { Fall P } \\
\text { applications }\end{array}$ & $\begin{array}{l}\text { Applied all P-containing fertilizers and manures in the fall season (post- } \\
\text { harvest) for corn and soybeans. }\end{array}$ \\
\hline \multirow[t]{4}{*}{ Cover crops } & $\begin{array}{l}\text { Tillage radish } \\
\text { after wheat }\end{array}$ & $\begin{array}{l}\text { Planted an annual cover crop, tillage radish (\#121 in plant.dat), in the } \\
\text { fall }(9 / 21) \text { after harvest of winter wheat, and killed it in the spring } \\
(4 / 15) \text { prior to planting corn. }\end{array}$ \\
\hline & $\begin{array}{l}\text { Cereal rye after } \\
\text { soybeans and } \\
\text { wheat }\end{array}$ & $\begin{array}{l}\text { Planted a perennial cover crop, cereal rye (\#30 in plant.dat), in the fall } \\
(\sim 9 / 21) \text { after harvest of soybeans (provided the next crop was not } \\
\text { wheat) and winter wheat, and killed it in the spring }(4 / 15) \text { prior to } \\
\text { planting corn or soybeans. }\end{array}$ \\
\hline & $\begin{array}{l}\text { Cereal rye after } \\
\text { soybeans, tillage } \\
\text { radish after } \\
\text { wheat }\end{array}$ & $\begin{array}{l}\text { Planted cereal rye in the fall after harvest of soybeans (provided the } \\
\text { next crop was not wheat), and tillage radish in the fall after harvest of } \\
\text { winter wheat. Similar management to those above. }\end{array}$ \\
\hline & $\begin{array}{l}\text { Cereal rye after } \\
\text { corn, soybeans, } \\
\text { and wheat }\end{array}$ & $\begin{array}{l}\text { Planted cereal rye in the fall after harvest of corn and soybeans } \\
\text { (provided the next crop was not wheat), and winter wheat. Similar } \\
\text { management to those above. }\end{array}$ \\
\hline \multirow[t]{3}{*}{$\begin{array}{l}\text { Vegetated filter } \\
\text { strips }\end{array}$} & $\begin{array}{l}\text { Poor-quality } \\
\text { filter strips }\end{array}$ & $\begin{array}{l}\text { Applied a filter strip (MGT_OP }=4, \text { FILTER_I }=1 \text { ) in the beginning of } \\
\text { the simulation period in the .ops file. The poor effectiveness was } \\
\text { simulated by a field area to filter strip area ratio of } 67: 1 \\
\text { (FILTER_RATIO }=67), 75 \% \text { of the field draining to the most } \\
\text { concentrated } 10 \% \text { of the filter (FILTER_CON }=0.75 \text { ), and } 50 \% \text { of the } \\
\text { most concentrated flow is fully channelized (FILTER_CH }=0.5 \text { ). }\end{array}$ \\
\hline & $\begin{array}{l}\text { Medium-quality } \\
\text { filter strips }\end{array}$ & $\begin{array}{l}\text { Applied a filter strip (MGT_OP }=4 \text {, FILTER_I }=1 \text { ) in the beginning of } \\
\text { the simulation period in the .ops file. The medium-quality filter strip } \\
\text { was simulated by a field area to filter strip area ratio of } 33: 1 \\
\text { (FILTER_RATIO }=33 \text { ), } 50 \% \text { of the field draining to the most } \\
\text { concentrated } 10 \% \text { of the filter (FILTER_CON }=0.5 \text { ), and } 25 \% \text { of the } \\
\text { most concentrated flow is fully channelized (FILTER_CH }=0.25 \text { ). }\end{array}$ \\
\hline & $\begin{array}{l}\text { High-quality } \\
\text { filter strips }\end{array}$ & $\begin{array}{l}\text { Applied a filter strip (MGT_OP }=4 \text {, FILTER_I }=1 \text { ) in the beginning of } \\
\text { the simulation period in the .ops file. The high-quality filter strip was } \\
\text { simulated by a field area to filter strip area ratio of } 22: 1 \\
\text { (FILTER_RATIO }=22 \text { ), } 25 \% \text { of the field draining to the most } \\
\text { concentrated } 10 \% \text { of the filter (FILTER_CON }=0.25 \text { ), and none of the } \\
\text { most concentrated flow is fully channelized (FILTER_CH }=0 \text { ). }\end{array}$ \\
\hline
\end{tabular}




\section{SWAT source code change}

We altered the source code of SWAT 2012 Revision 635 to correct a bug preventing soluble P from flowing through tile drains. The bug fixes were made as follows:

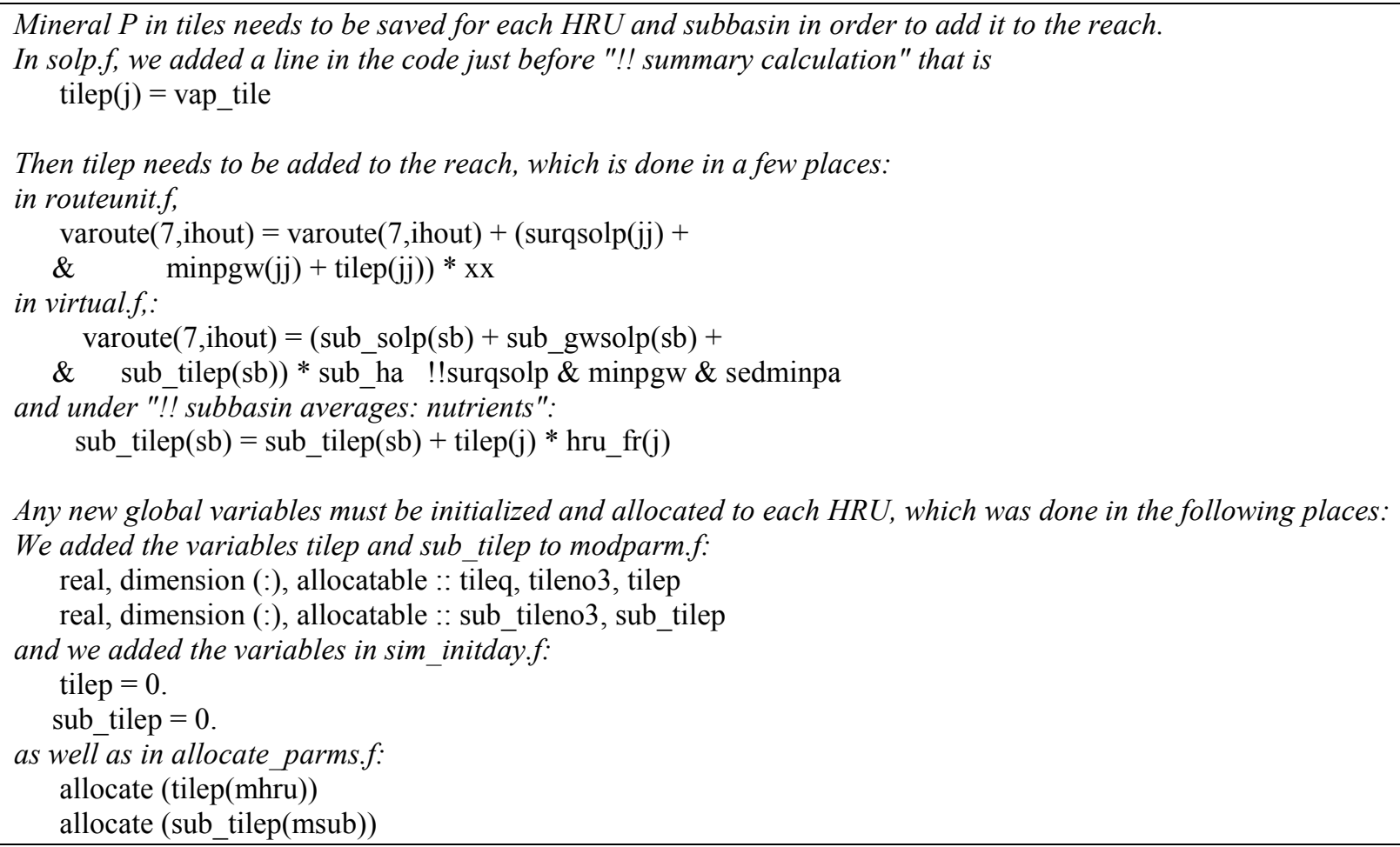

We also created HRU and subbasin-level outputs to track tilep flows in the program. We compiled the executable using gfortran, which must take a slightly different format from the compiler used by the SWAT team, and so there were some spacing and semantic bug fixes needed to properly compile the program. We tested that the new executable produced the same outputs, aside from the tile P, as the version downloaded from the SWAT website (http://swat.tamu.edu/software/swat-executables/).

The SWAT team (Jeff Arnold and Nancy Sammons) was made aware of this bug in March of 2015, when we shared these code fixes with them, and in October of 2015 we heard that the team had made the fix in their internal version of the source code, but as of June 2016 the latest revision (637) available on the SWAT website, and released in May 2015, does not include these bug fixes. 


\section{SWAT model calibration and validation}

\section{Calibration statistics}

The Nash-Sutcliffe Efficiency (NSE) is defined as:

$$
N S E=1-\frac{\sum_{i=1}^{n}\left(Y_{i}^{o b s}-Y_{i}^{s i m}\right)^{2}}{\sum_{i=1}^{n}\left(Y_{i}^{o b s}-Y_{\text {mean }}^{o b s}\right)^{2}}
$$

where $Y$ is the constituent of interest (e.g. streamflow, TP load), obs is observed data, sim is model simulated data, and $i$ is the time step from the start $(i=1)$ until the end $(i=n)$ of the time period. $Y_{\text {mean }}{ }^{o b s}$ is the average observed data from the complete time period. NSE ranges from negative infinity to 1 , and a value above 0 and close to 1 indicates good fit.

Similarly, the Percent Bias (PBIAS) is defined as:

$$
P B I A S=100 \times \frac{\sum_{i=1}^{n}\left(Y_{i}^{s i m}-Y_{i}^{o b s}\right)}{\sum_{i=1}^{n}\left(Y_{i}^{o b s}\right)}
$$

which assesses the over- $(+)$ and under-prediction (-) of a model compared to measured data, varies from negative infinity to infinity, and a value close to 0 indicates a good fit.

The correlation coefficient $\left(R^{2}\right)$ is the square of the Pearson's correlation (R). 
Graphical measures for the calibration period (2001-2006)
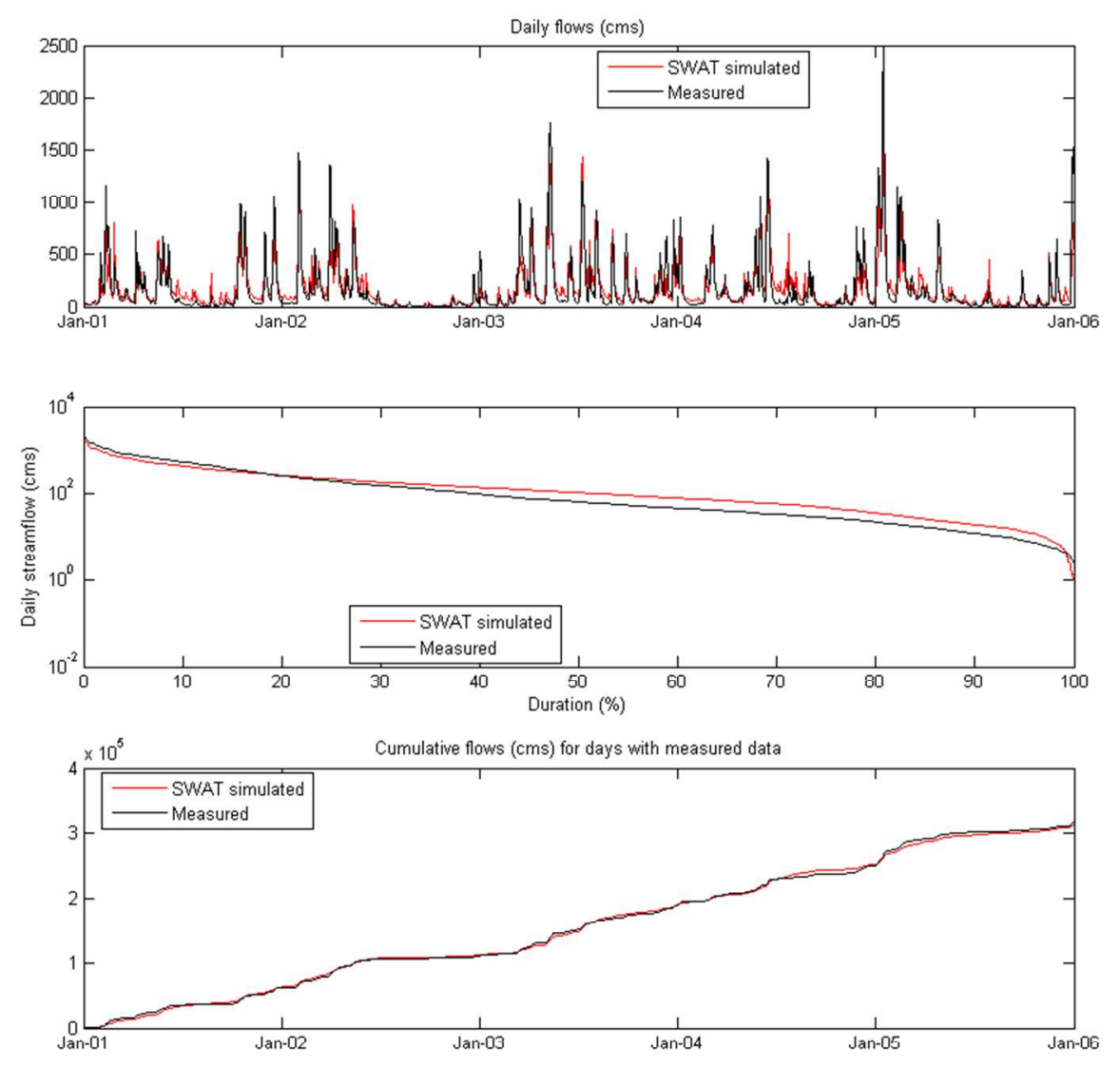

Figure S4: Calibration graphs for flow at Waterville, $\mathrm{OH}$. 

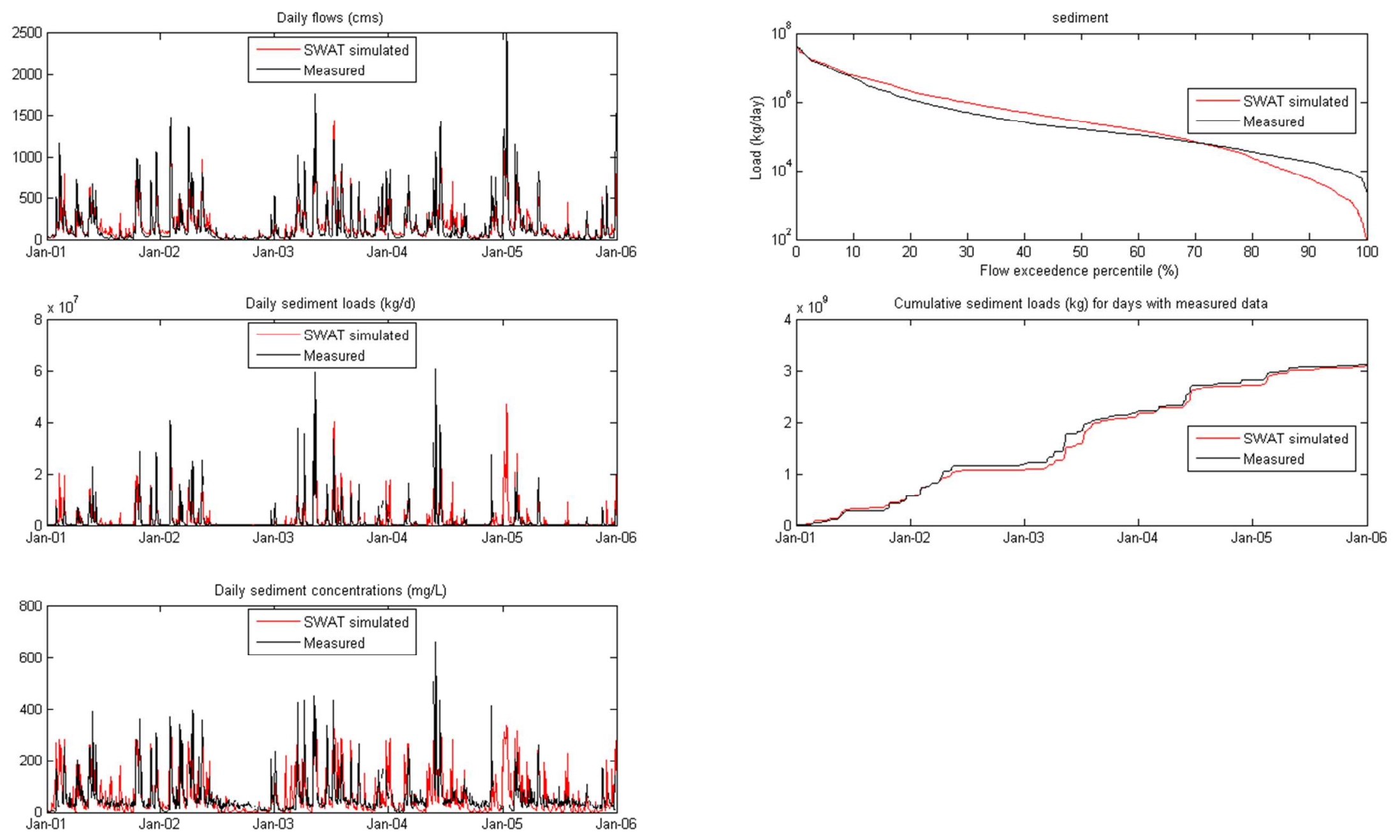

Figure S5: Calibration graphs for sediment loading at Waterville, $\mathrm{OH}$. 

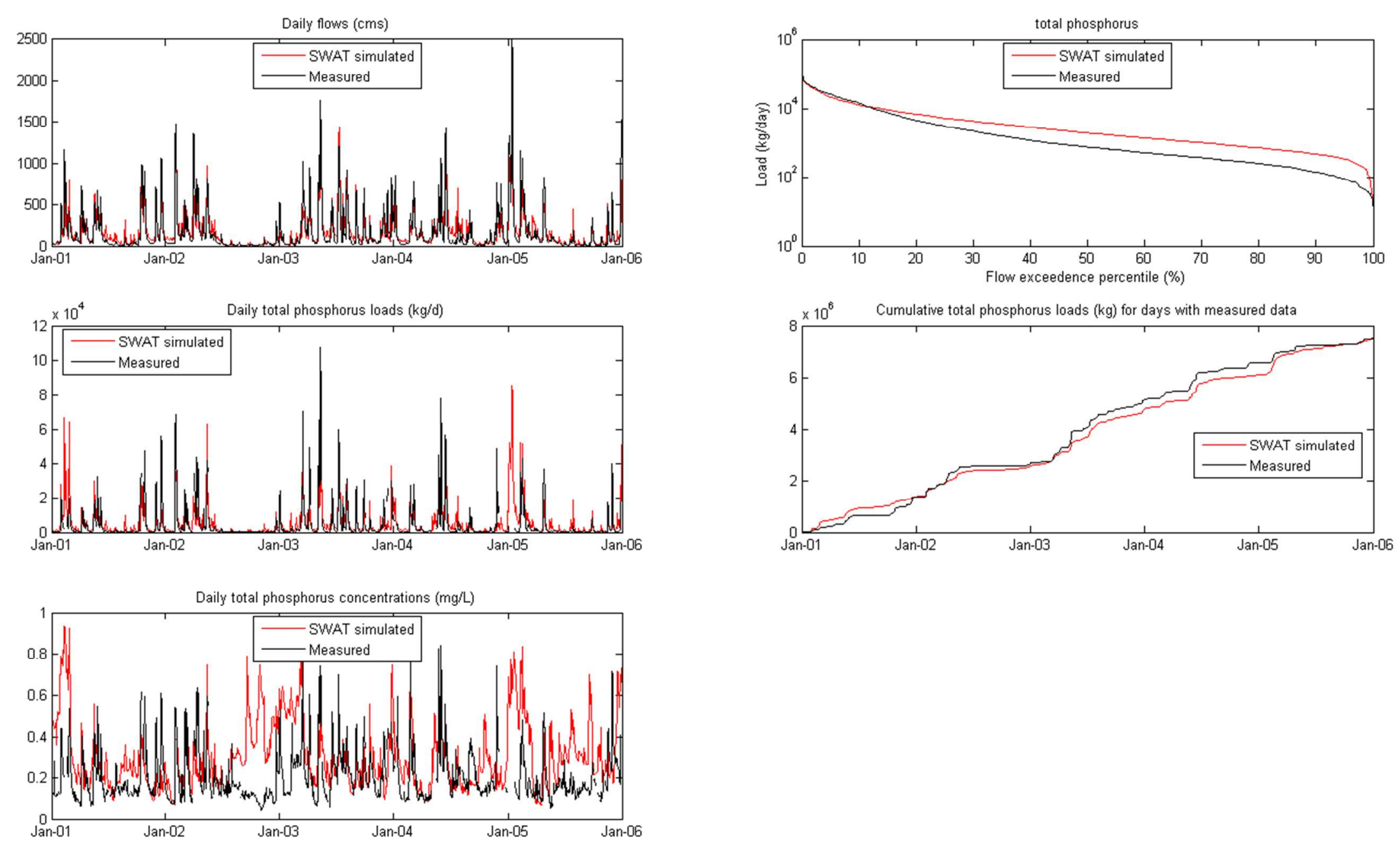

Figure S6: Calibration graphs for TP loading at Waterville, $\mathrm{OH}$. 

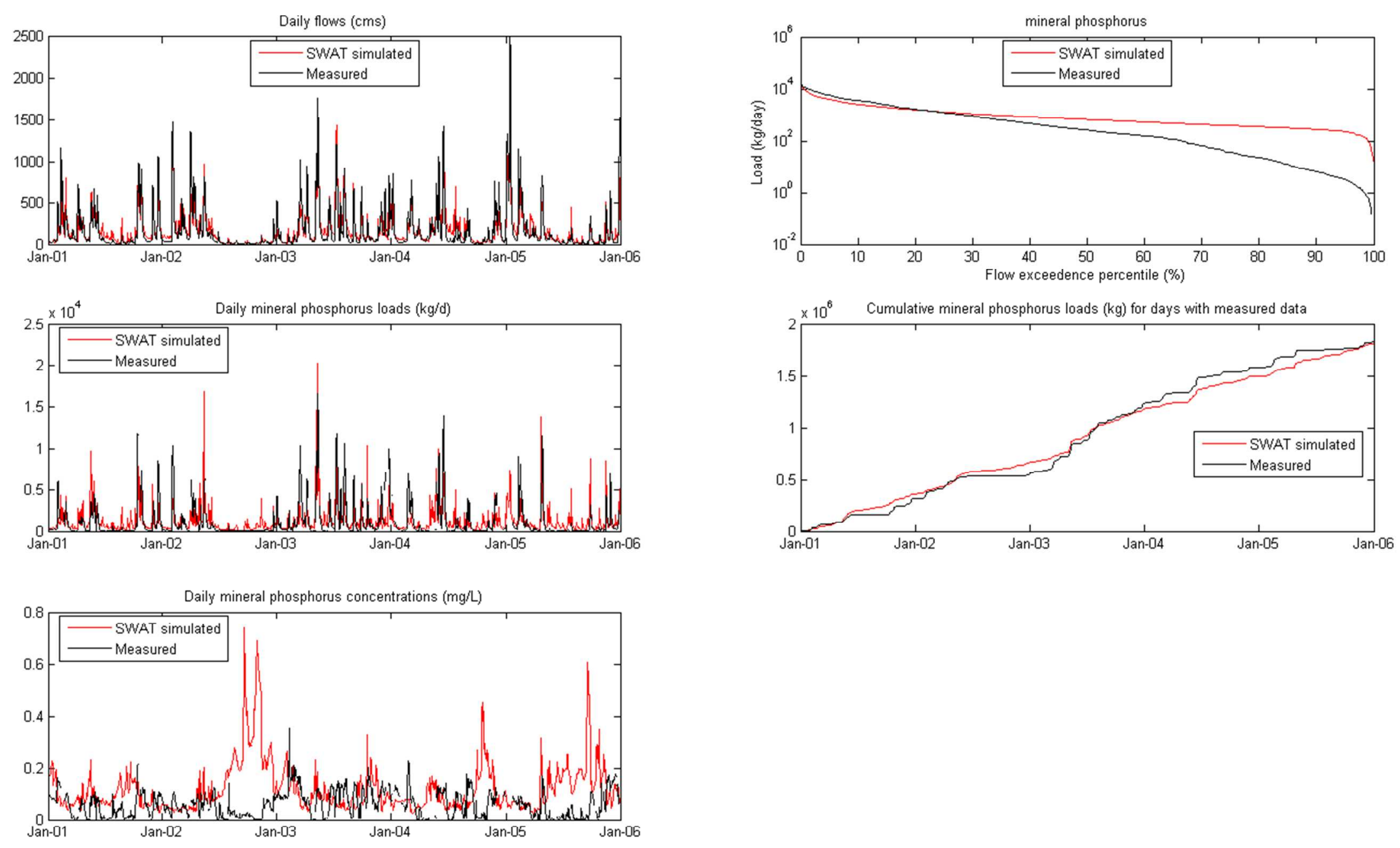

Figure S7: Calibration graphs for DRP loading at Waterville, OH. "Mineral phosphorus" in SWAT was the closest proxy for DRP. 

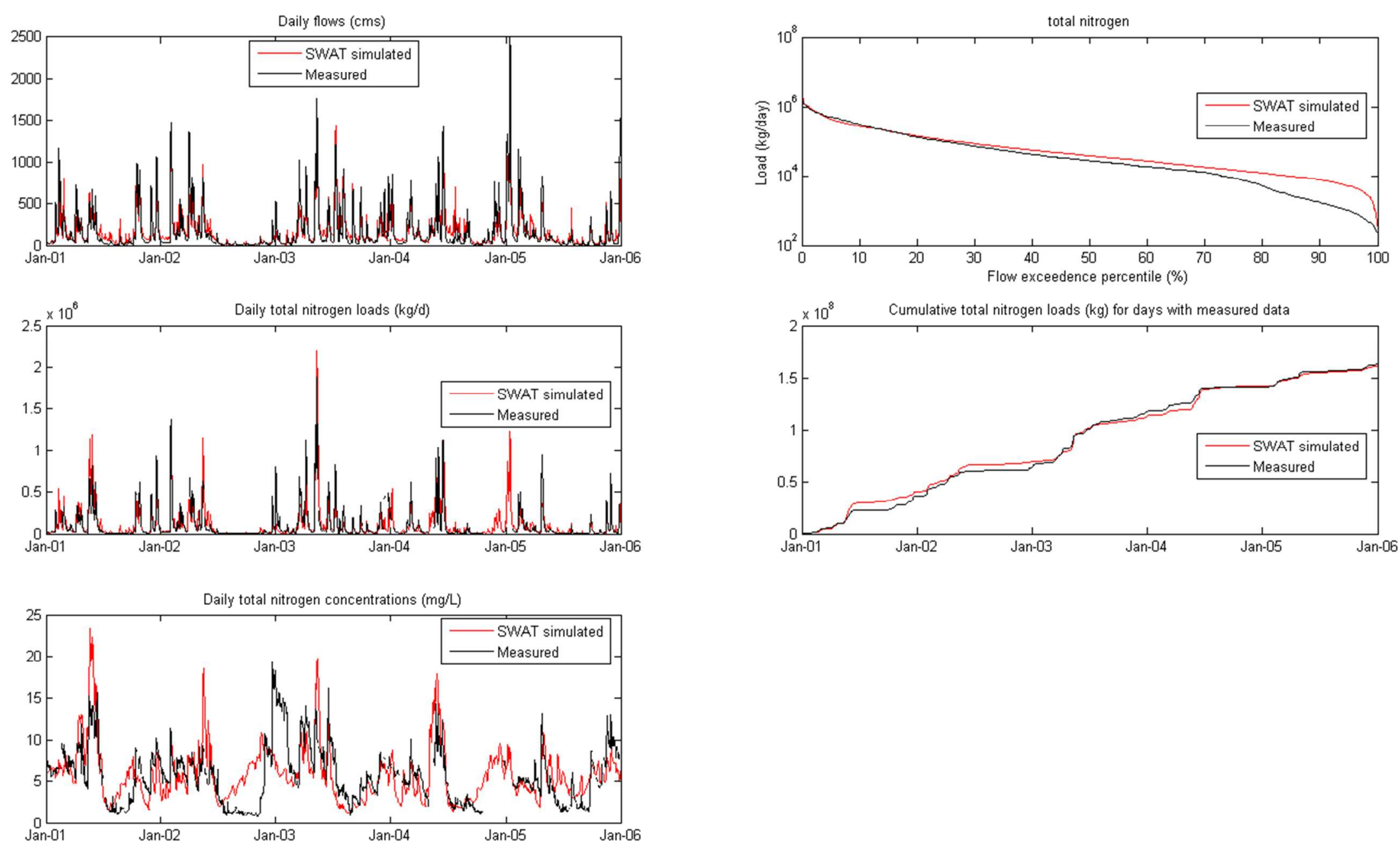

Figure S8: Calibration graphs for TN loading at Waterville, $\mathrm{OH}$. 

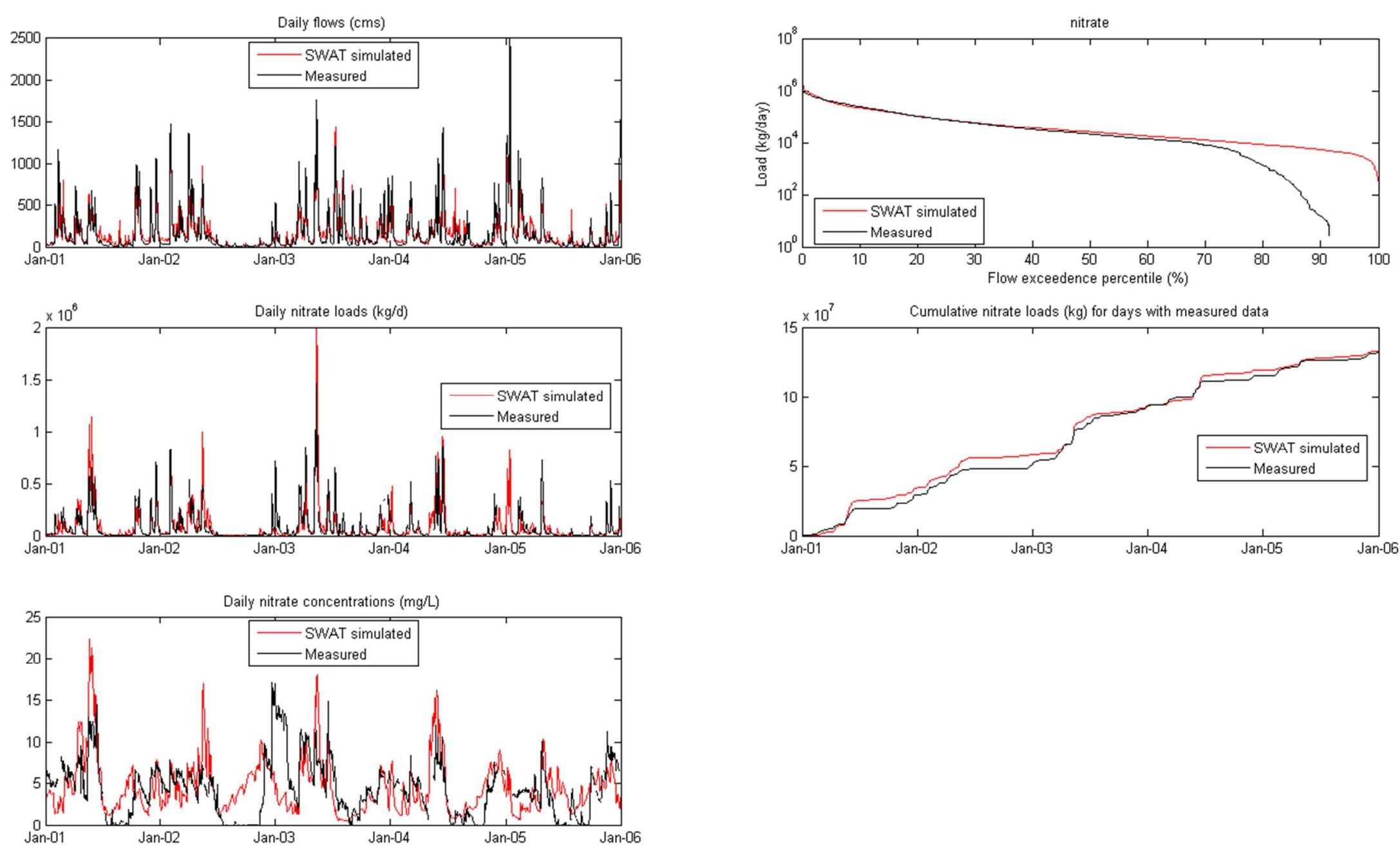

Figure S9: Calibration graphs for nitrate loading at Waterville, $\mathrm{OH}$. 
Graphics measures for the validation period (2001-2006)
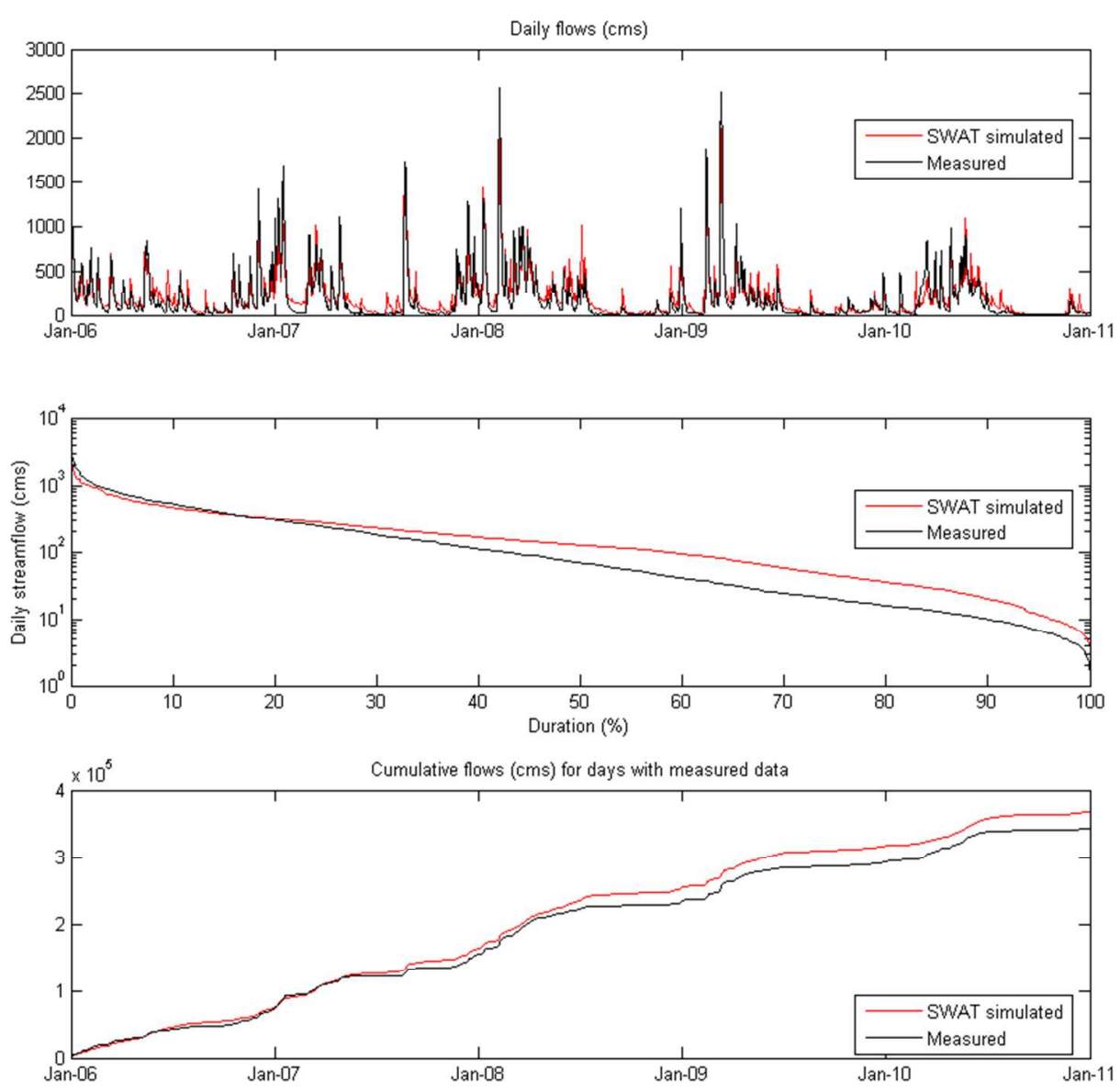

Figure S10: Validation graphs for flow at Waterville, $\mathrm{OH}$. 

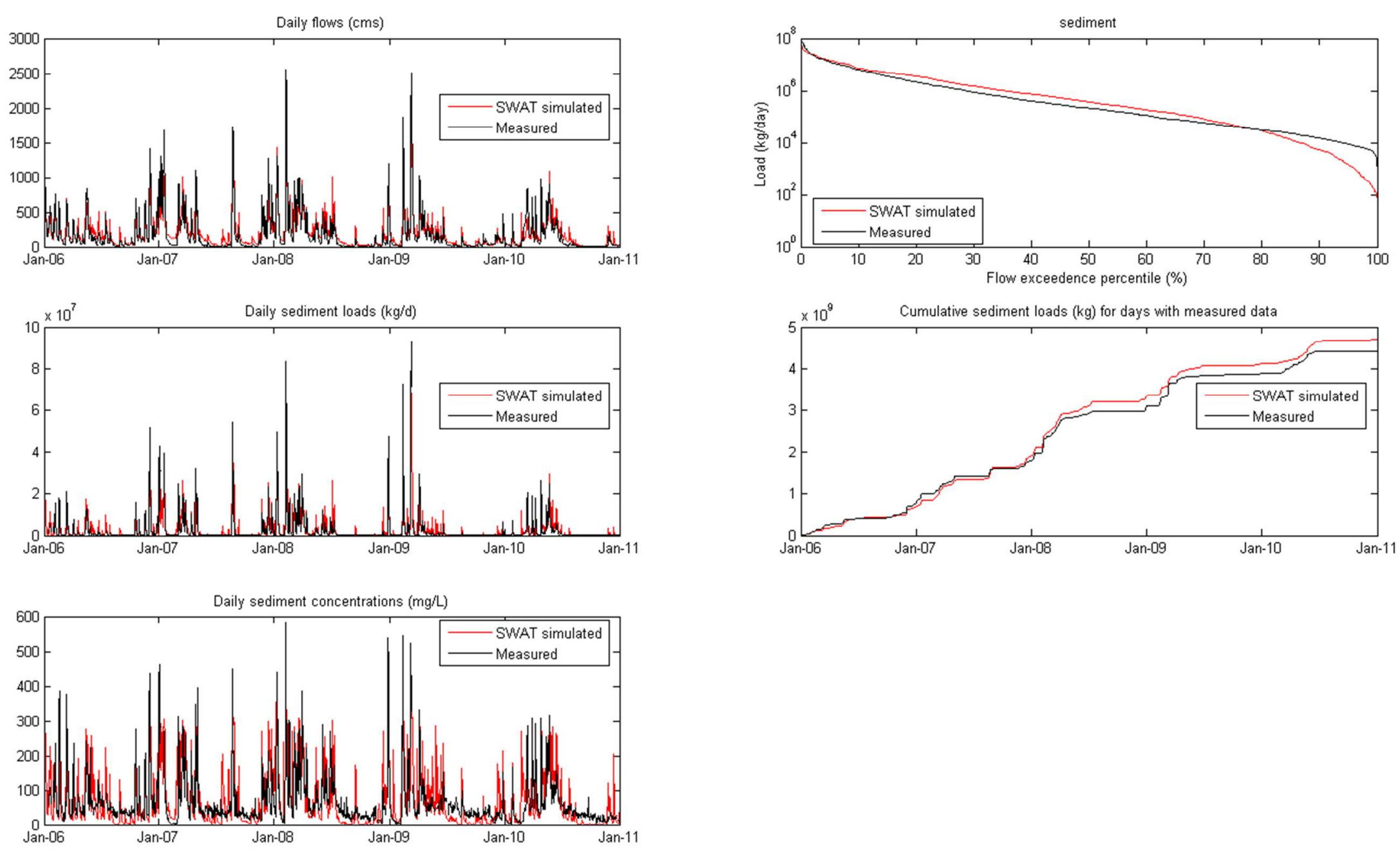

Figure S11: Validation graphs for sediment at Waterville, $\mathrm{OH}$. 

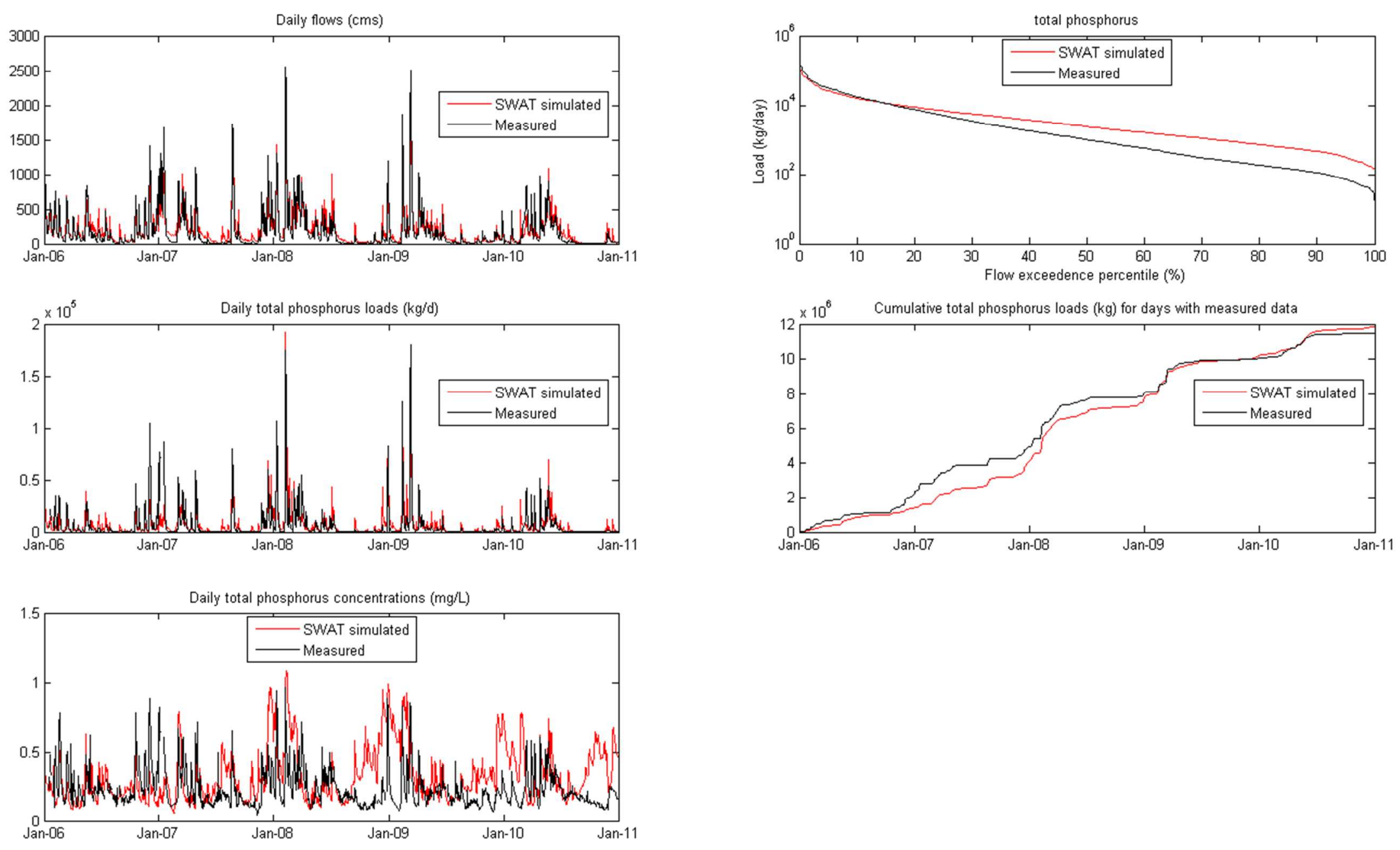

Figure S12: Validation graphs for $\mathrm{TP}$ at Waterville, $\mathrm{OH}$. 

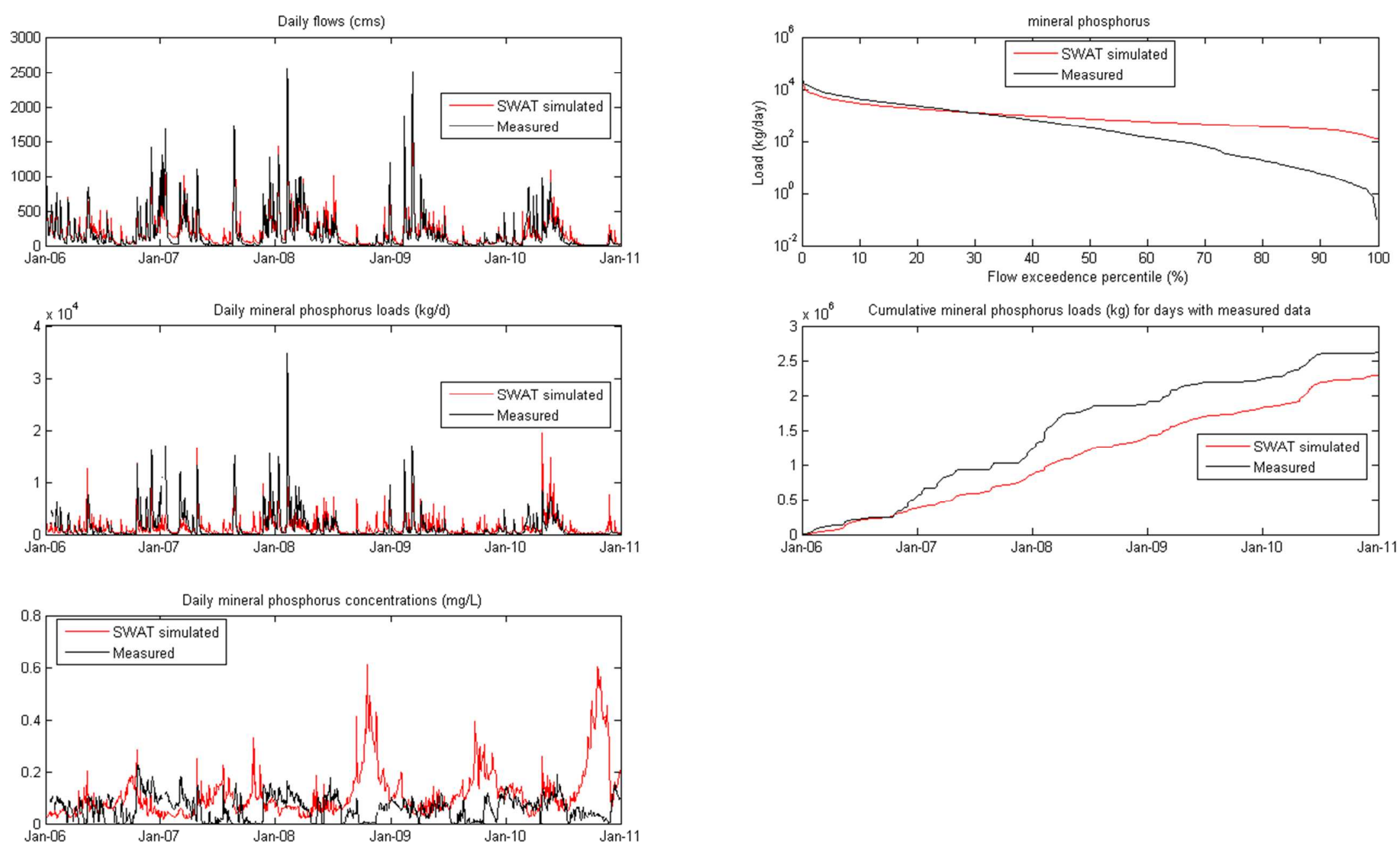

Figure S13: Validation graphs for DRP at Waterville, OH. "Mineral phosphorus" in SWAT was the closest proxy for DRP. 

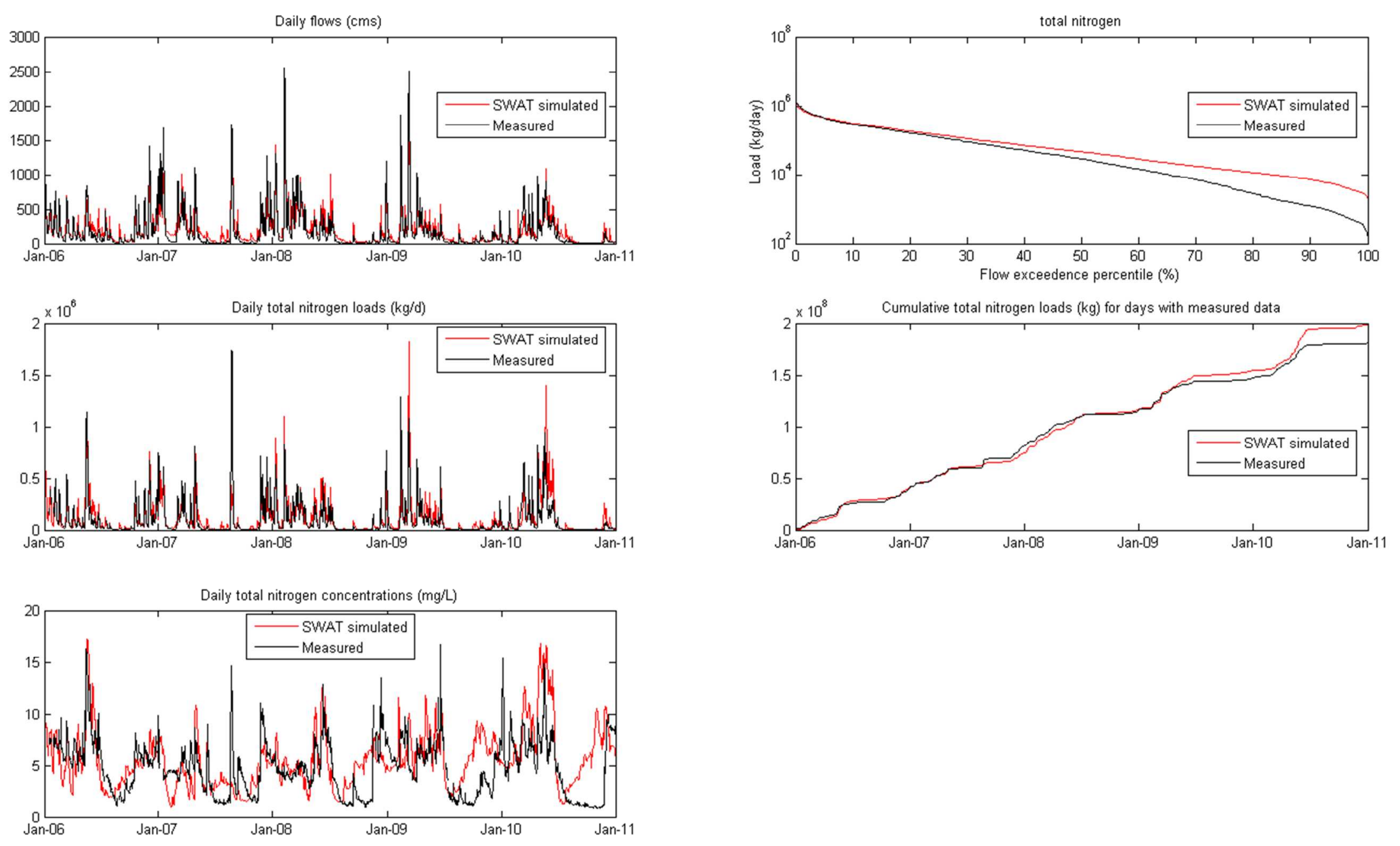

Figure S14: Validation graphs for $\mathrm{TN}$ at Waterville, $\mathrm{OH}$. 

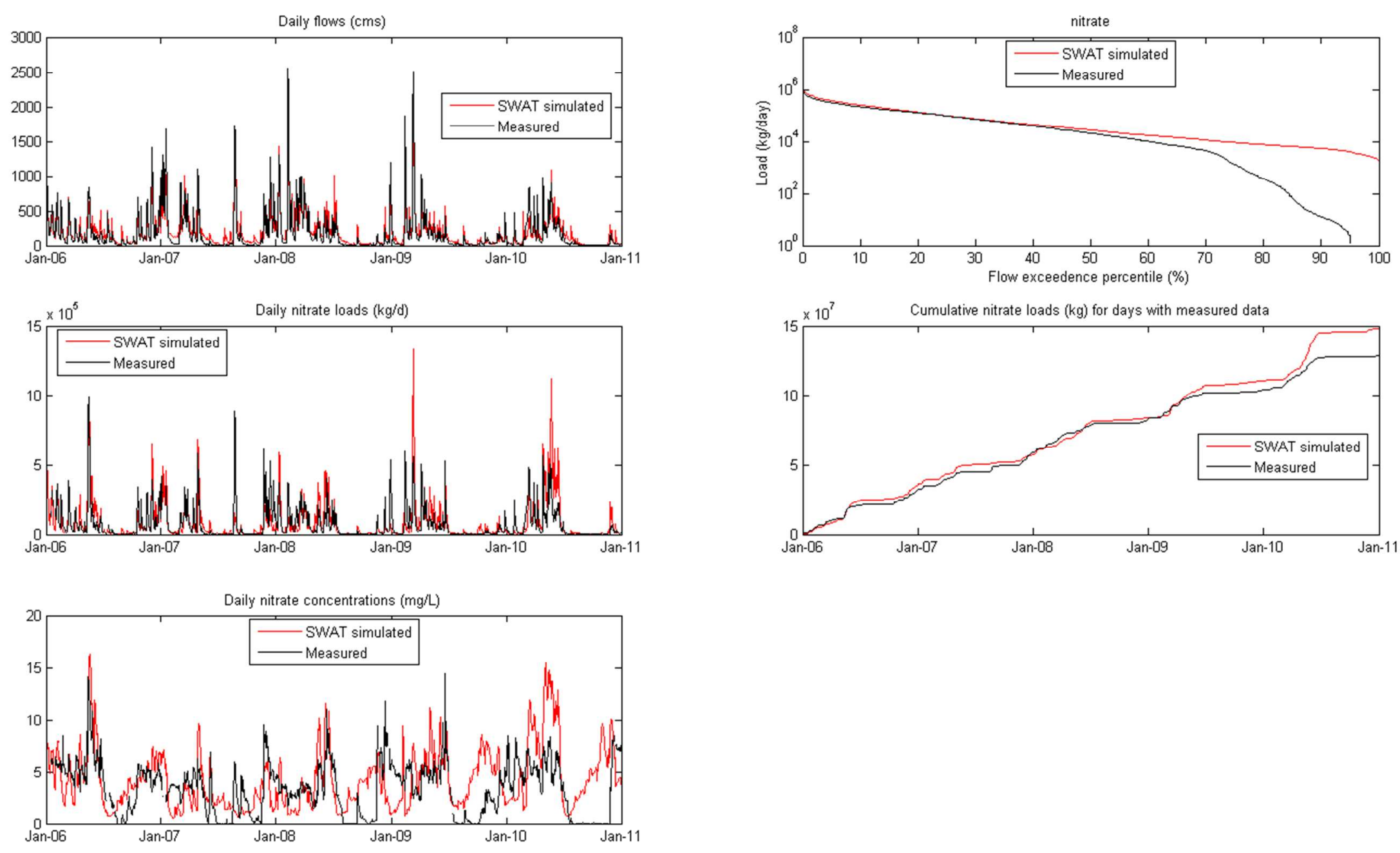

Figure S15: Validation graphs for nitrate at Waterville, $\mathrm{OH}$. 


\section{0-year annual, monthly, and daily time series plots}
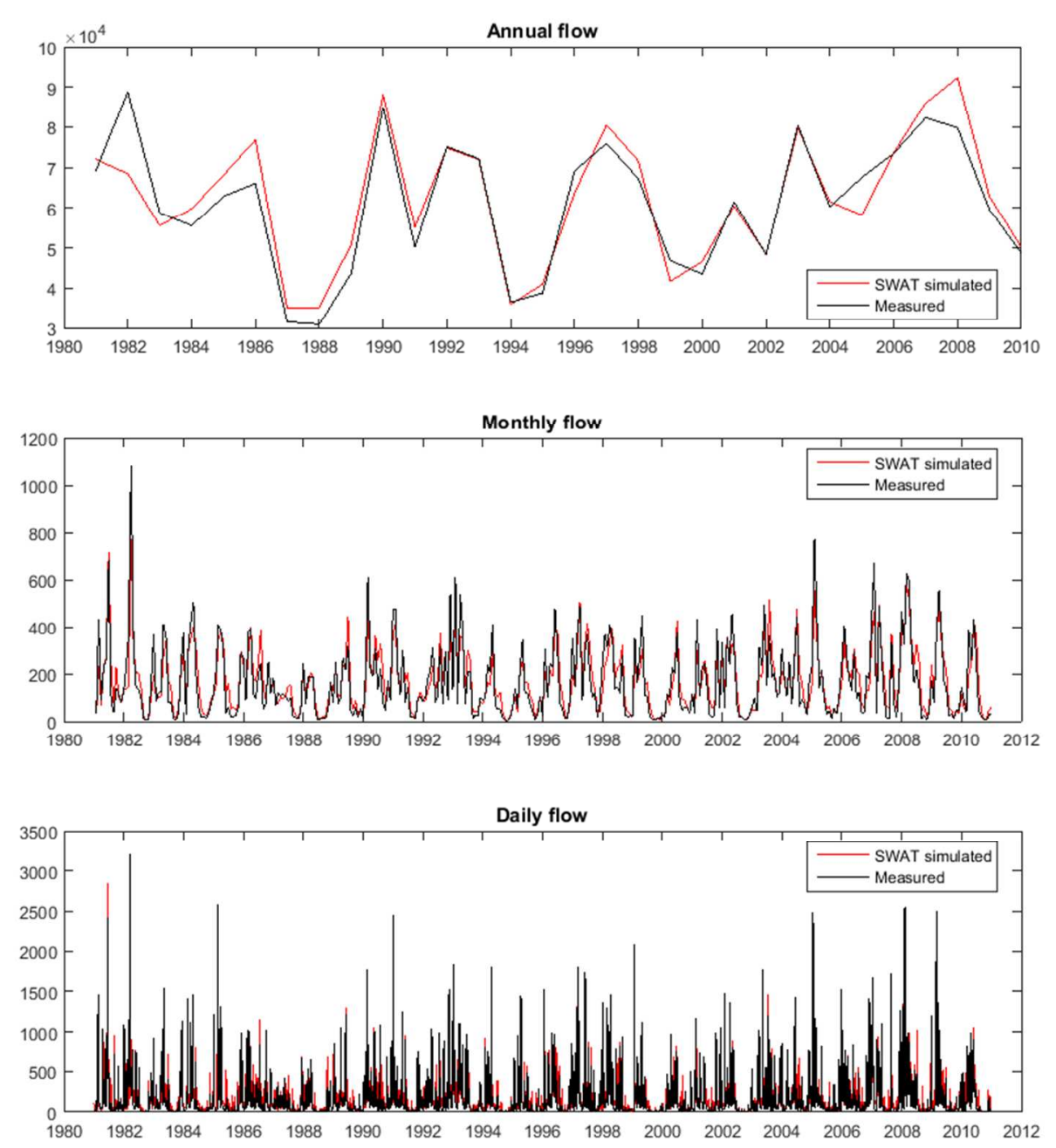

Figure S16: 30-year time series plots of daily, monthly, and annual flow at Waterville, $\mathrm{OH}$. 

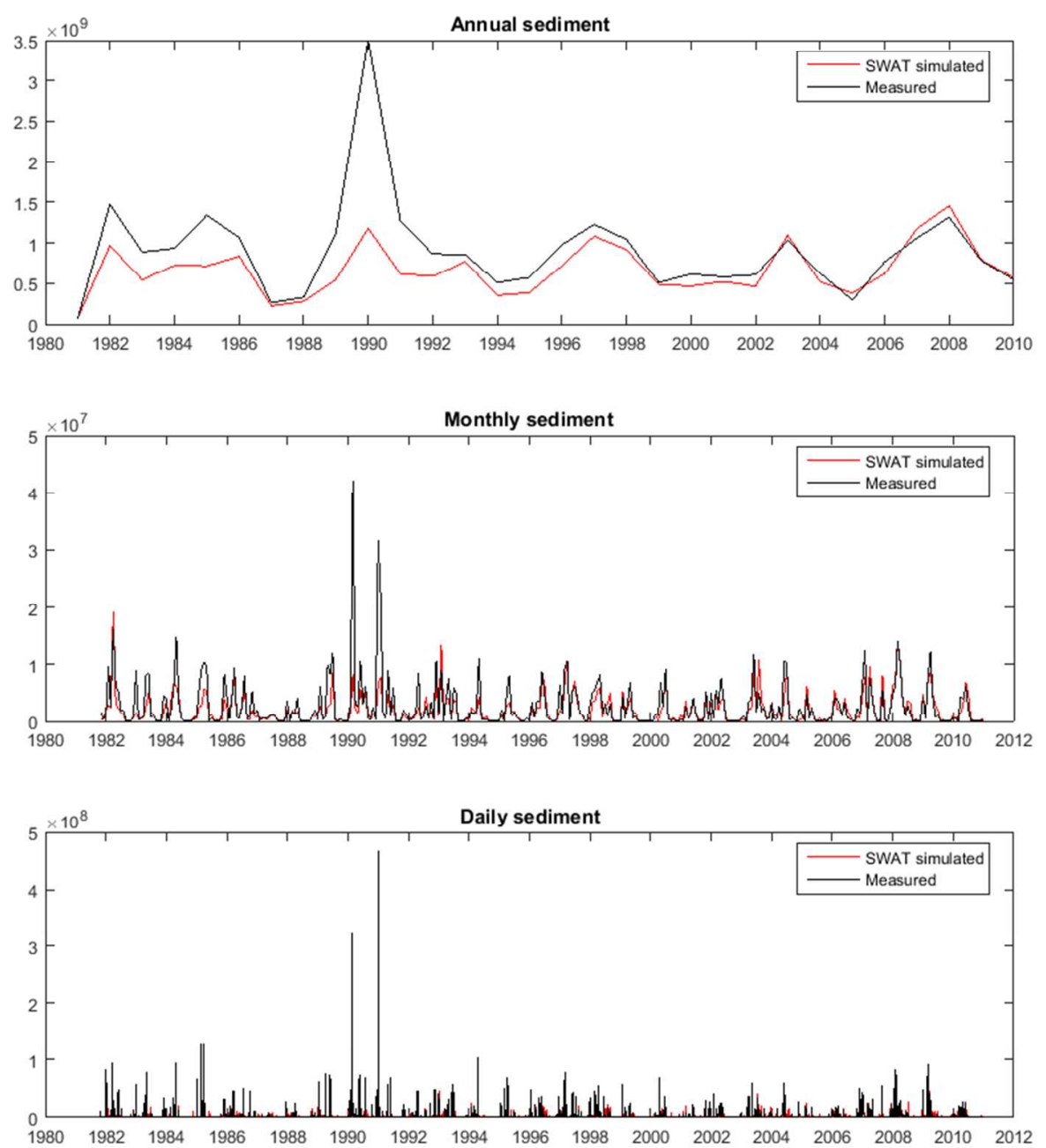

Figure S17: 30-year time series plots of daily, monthly, and annual sediment loading at Waterville, $\mathrm{OH}$. 

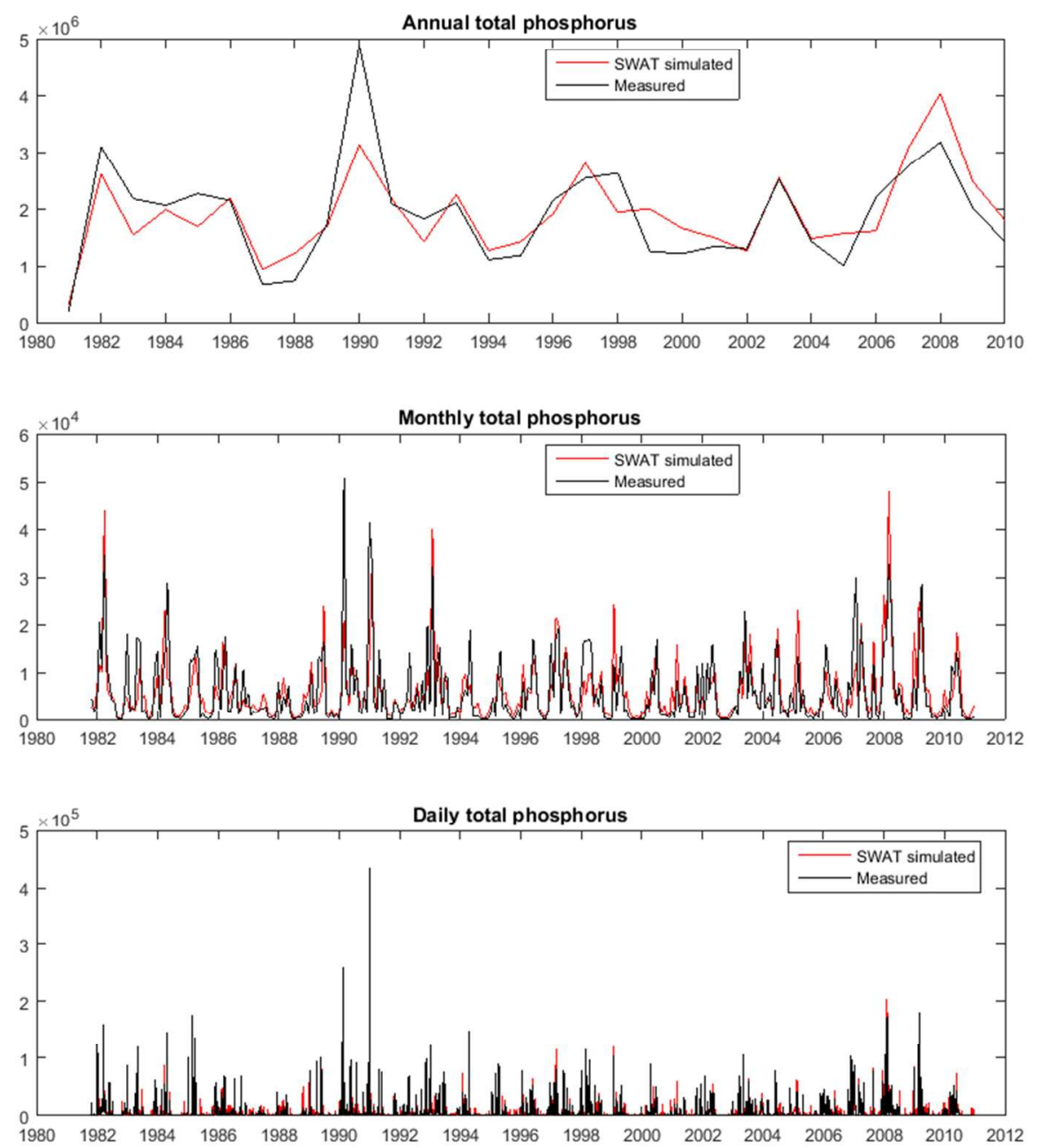

Figure S18: 30-year time series plots of daily, monthly, and annual TP loading at Waterville, OH. 

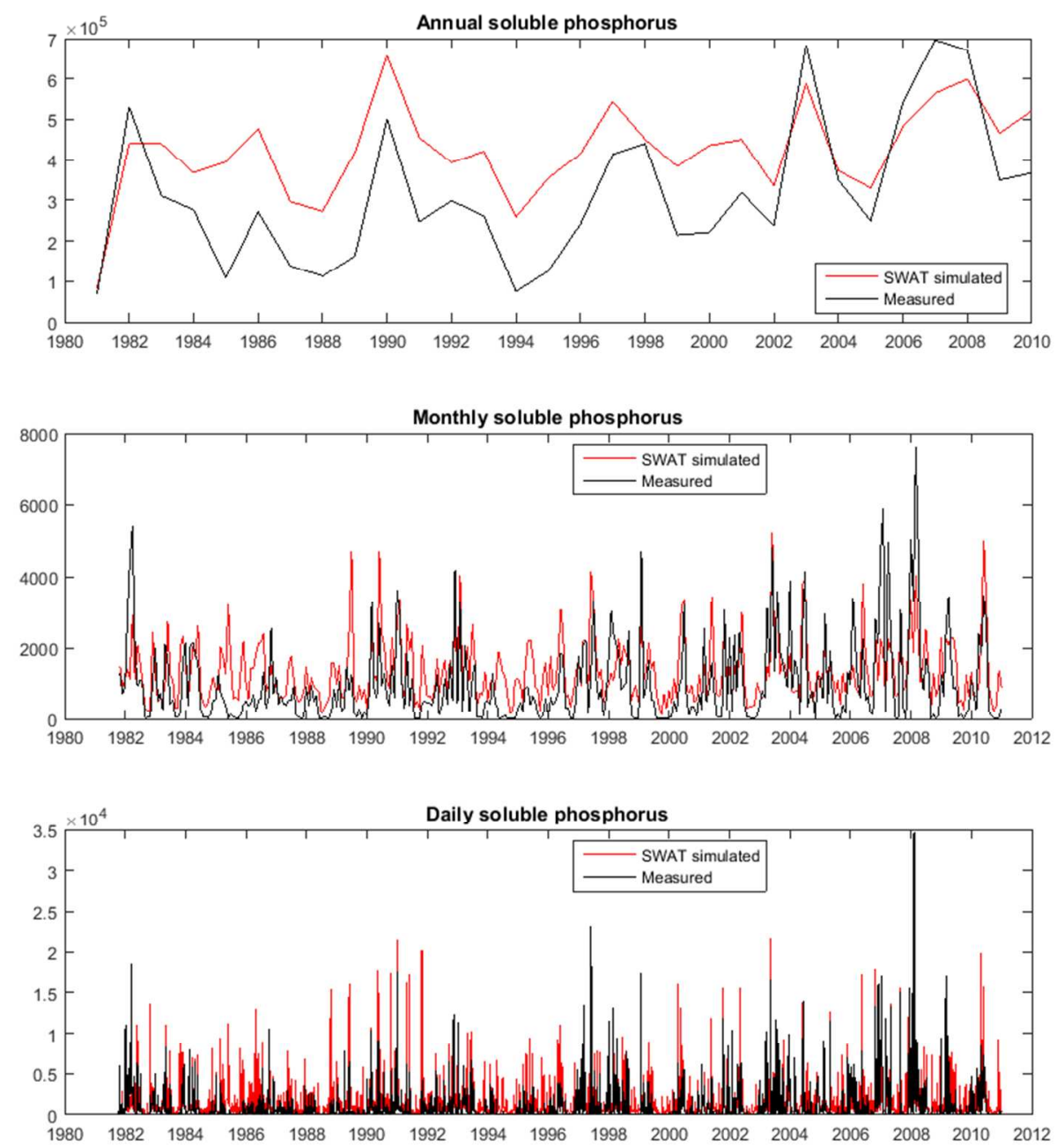

Figure S19: 30-year time series plots of daily, monthly, and annual DRP loading at Waterville, $\mathrm{OH}$. 

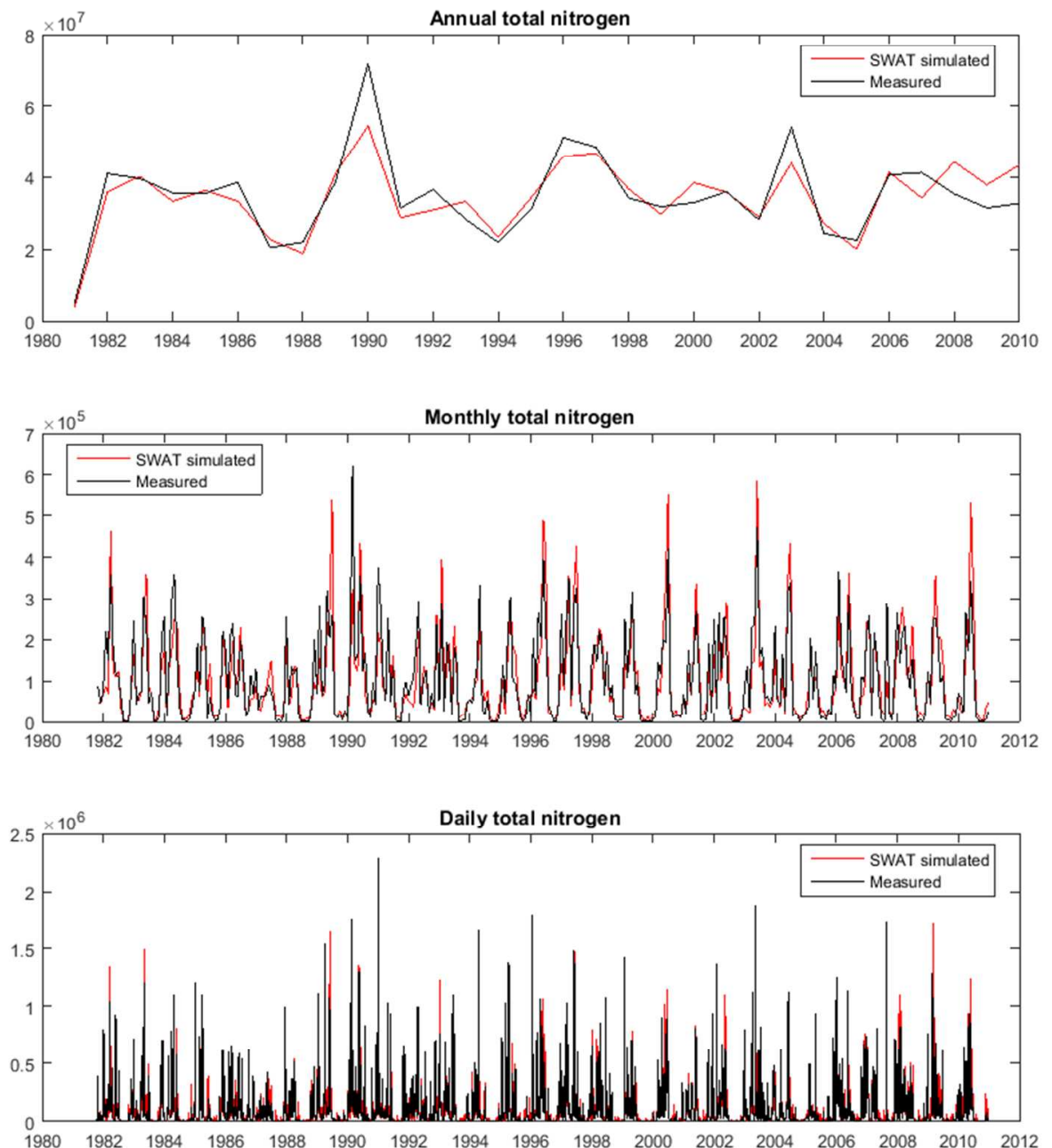

Figure S20: 30-year time series plots of daily, monthly, and annual TN loading at Waterville, $\mathrm{OH}$. 

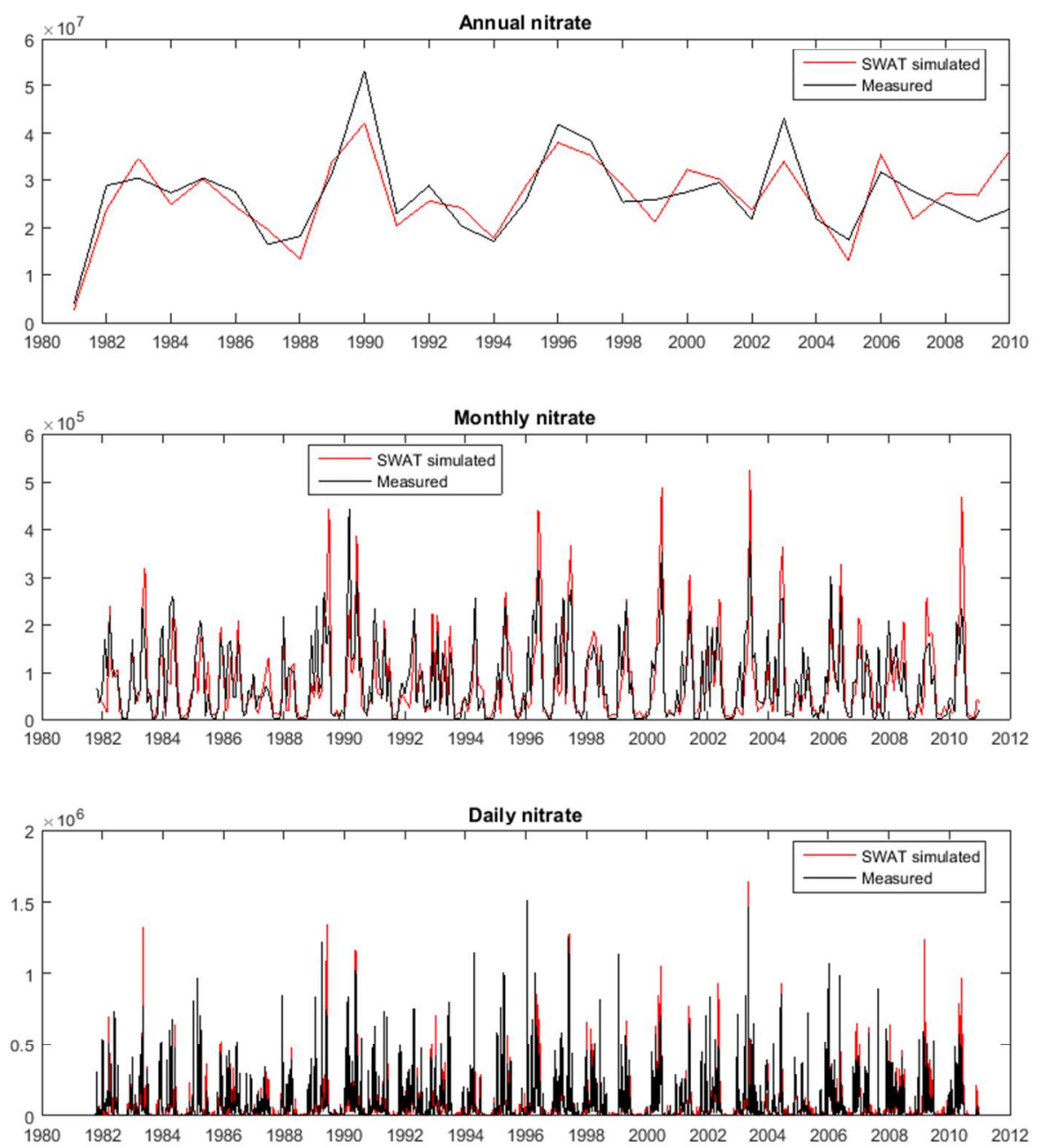

Figure S21: 30-year time series plots of daily, monthly, and annual nitrate loading at Waterville, $\mathrm{OH}$. 


\section{Predicted vs. observed plots}
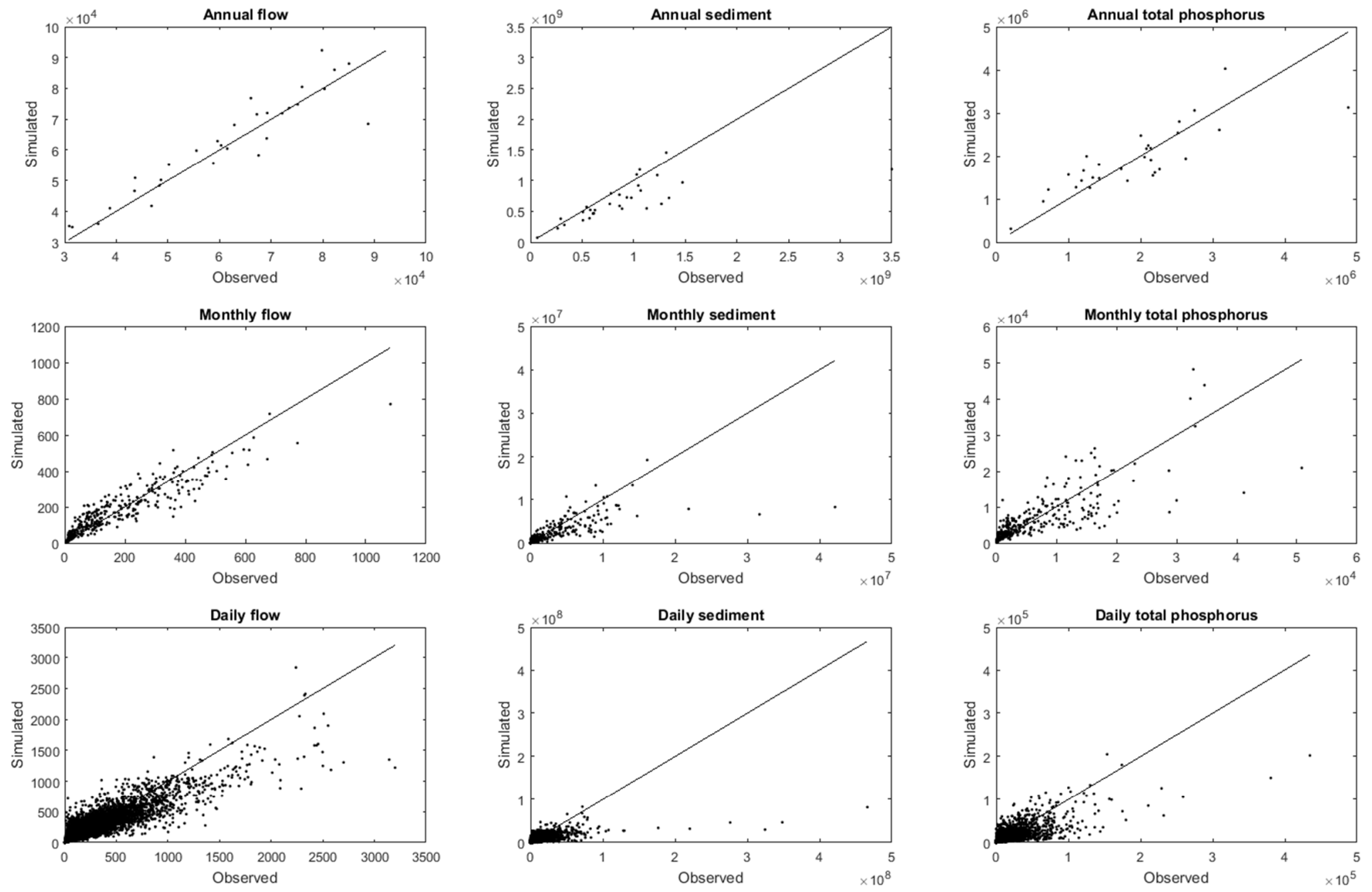

Figure S22: Predicted vs. observed plots for flow (left), sediment (middle), and TP (right) loading at Waterville, OH. 

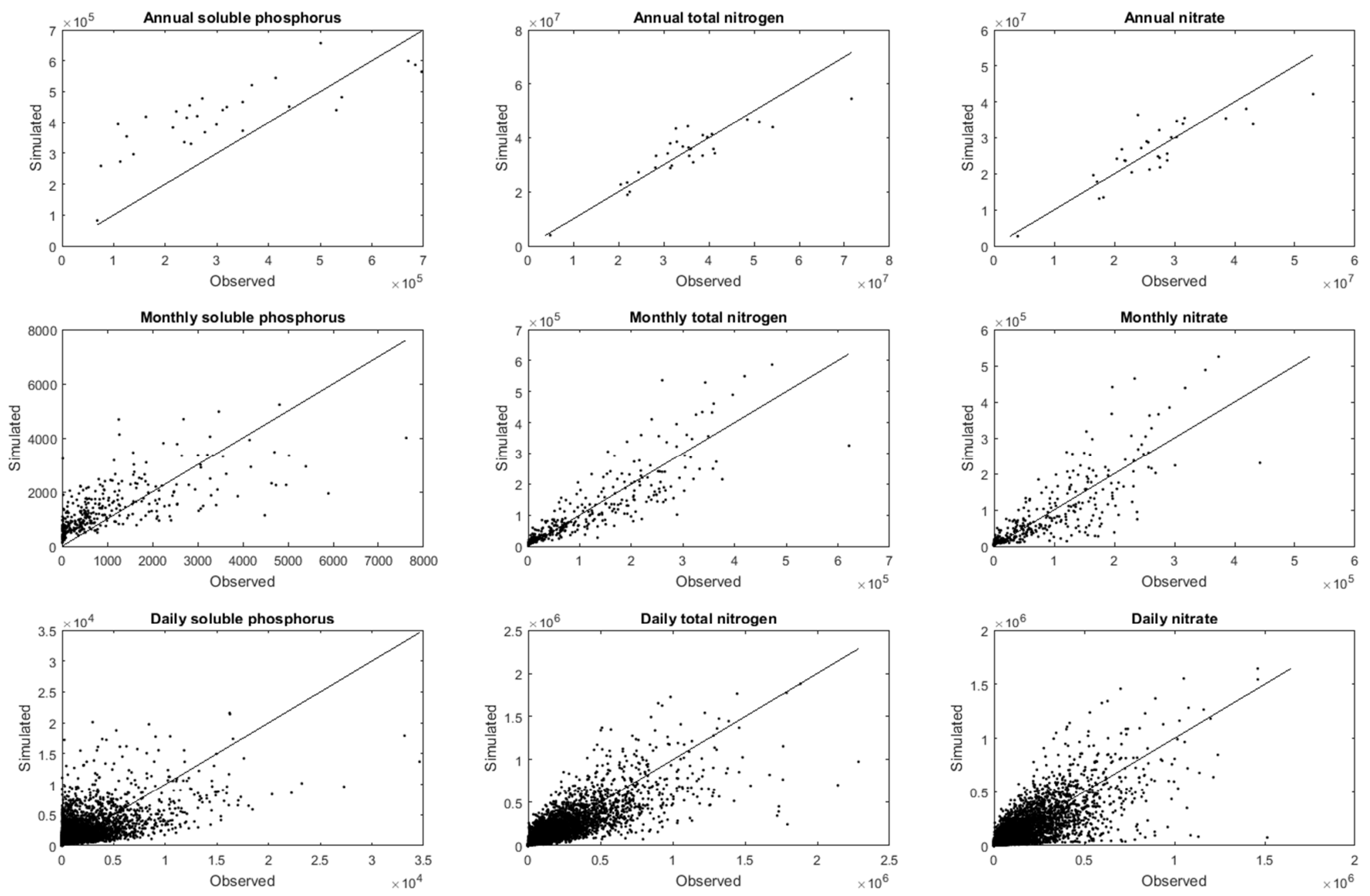

Figure S23: Predicted vs. observed plots for DRP (left), TN (middle), and nitrate (right) loading at Waterville, $\mathrm{OH}$. 